\title{
Quantifying the contributions to stratospheric ozone changes from ozone depleting substances and greenhouse gases
}

\author{
D. A. Plummer ${ }^{1}$, J. F. Scinocca ${ }^{1}$, T. G. Shepherd ${ }^{2}$, M. C. Reader ${ }^{1}$, and A. I. Jonsson ${ }^{2}$ \\ ${ }^{1}$ Canadian Centre for Climate Modelling and Analysis, Environment Canada, Victoria, BC, Canada \\ ${ }^{2}$ Department of Physics, University of Toronto, Toronto, Canada \\ Received: 22 March 2010 - Published in Atmos. Chem. Phys. Discuss.: 15 April 2010 \\ Revised: 1 September 2010 - Accepted: 6 September 2010 - Published: 20 September 2010
}

\begin{abstract}
A state-of-the-art chemistry climate model coupled to a three-dimensional ocean model is used to produce three experiments, all seamlessly covering the period 1950-2100, forced by different combinations of long-lived Greenhouse Gases (GHGs) and Ozone Depleting Substances (ODSs). The experiments are designed to quantify the separate effects of GHGs and ODSs on the evolution of ozone, as well as the extent to which these effects are independent of each other, by alternately holding one set of these two forcings constant in combination with a third experiment where both ODSs and GHGs vary. We estimate that up to the year 2000 the net decrease in the column amount of ozone above $20 \mathrm{hPa}$ is approximately $75 \%$ of the decrease that can be attributed to ODSs due to the offsetting effects of cooling by increased $\mathrm{CO}_{2}$. Over the 21 st century, as ODSs decrease, continued cooling from $\mathrm{CO}_{2}$ is projected to account for more than $50 \%$ of the projected increase in ozone above $20 \mathrm{hPa}$. Changes in ozone below $20 \mathrm{hPa}$ show a redistribution of ozone from tropical to extra-tropical latitudes with an increase in the Brewer-Dobson circulation. In addition to a latitudinal redistribution of ozone, we find that the globally averaged column amount of ozone below $20 \mathrm{hPa}$ decreases over the 21 st century, which significantly mitigates the effect of upper stratospheric cooling on total column ozone. Analysis by linear regression shows that the recovery of ozone from the effects of ODSs generally follows the decline in reactive chlorine and bromine levels, with the exception of the lower polar stratosphere where recovery of ozone in the second half of the 21 st century is slower than would be indicated by the decline in reactive chlorine and bromine concentra-
\end{abstract}

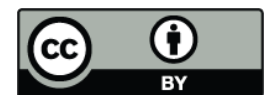

Correspondence to: D. A. Plummer (david.plummer@ec.gc.ca) tions. These results also reveal the degree to which GHGrelated effects mute the chemical effects of $\mathrm{N}_{2} \mathrm{O}$ on ozone in the standard future scenario used for the WMO Ozone Assessment. Increases in the residual circulation of the atmosphere and chemical effects from $\mathrm{CO}_{2}$ cooling more than halve the increase in reactive nitrogen in the mid to upper stratosphere that results from the specified increase in $\mathrm{N}_{2} \mathrm{O}$ between 1950 and 2100 .

\section{Introduction}

Evidence can now be seen in the atmosphere for the efficacy of the controls on emissions of halogenated species enacted as part of the Montreal Protocol and subsequent amendments. The tropospheric concentrations of many of the primary chlorine and bromine containing Ozone Depleting Substances (ODSs) peaked in the early 1990s and have continued to decrease (Montzka et al., 1999; WMO, 2007), while the stratospheric concentration of reactive chlorine has peaked more recently (WMO, 2007). Projections show the continued decrease of the atmospheric abundance of these species throughout the rest of the 21 st century.

As the anthropogenic perturbation to halogen concentrations in the stratosphere decreases, other influences on the stratosphere can be expected to play a greater role. Foremost among these is the effect of climate change, driven largely by increasing concentrations of $\mathrm{CO}_{2}$. Increased concentrations of $\mathrm{CO}_{2}$ cool the stratosphere, with the effect maximizing near the stratopause, and are believed to be responsible for approximately one half the observed cooling trend in the upper stratosphere (Shine et al., 2003; WMO, 2007). The cooling leads to an increase in the concentration of ozone through

Published by Copernicus Publications on behalf of the European Geosciences Union. 
the effect of temperature on chemical reaction rates (Haigh and Pyle, 1982; Brasseur and Hitchman, 1988), with the increased ozone acting to partly reverse the cooling (Jonsson et al., 2004). Cooling from increasing $\mathrm{CO}_{2}$ over the recent past is believed to have decreased ozone loss that would have otherwise occurred from ODSs by up to $20 \%$ in the upper stratosphere (Rosenfield et al., 2005; Jonsson et al., 2009). Continued future increases in $\mathrm{CO}_{2}$ are projected to result in upper stratospheric ozone recovering more rapidly than would be expected from declining ODSs alone and eventually producing upper stratospheric ozone concentrations larger than those found in the past, before significant ODS perturbations (Rosenfield et al., 2002).

Changing climate can also be expected to affect stratospheric ozone through changes to the residual circulation of the stratosphere. The Brewer-Dobson (B-D) circulation is driven by the dissipation of Rossby and gravity waves propagating upwards from the troposphere (e.g., Holton et al., 1995) and, as such, will be affected by changes in climate that modify the source and propagation of these waves. In fact, Chemistry-Climate Models (CCMs) have consistently shown an acceleration of the residual circulation as a result of climate change (Butchart et al., 2006), which can be expected to affect the vertical and latitudinal distribution of ozone and other long-lived chemical species in the stratosphere (Austin and Wilson, 2006; Shepherd, 2008; Waugh et al., 2009). However, it should be noted that there may be some discrepancy between model predictions of changes in the stratospheric circulation and estimated changes in age of air over the recent past inferred from the available observations (Engel et al., 2009).

In addition to increasing $\mathrm{CO}_{2}$ and climate change, stratospheric ozone may be affected by changing concentrations of other trace species. Reactions involving nitrogen oxides $\left(\mathrm{NO}_{\mathrm{x}}=\mathrm{NO}+\mathrm{NO}_{2}\right)$ form the dominant ozone catalytic loss cycles throughout much of the middle stratosphere. Therefore, changes in $\mathrm{N}_{2} \mathrm{O}$, the source gas for stratospheric $\mathrm{NO}_{\mathrm{x}}$, can be expected to have important effects on stratospheric ozone (Chipperfield and Feng, 2003; Portmann and Solomon, 2007). Water vapour will also play a role - affecting the radiative balance of the stratosphere and, as a source of $\mathrm{HO}_{\mathrm{x}}\left(\mathrm{OH}+\mathrm{HO}_{2}\right)$, playing an important role in ozone chemistry, particularly in the upper stratosphere. The concentration of stratospheric $\mathrm{H}_{2} \mathrm{O}$ may be affected by changes to the tropospheric concentration of $\mathrm{CH}_{4}$ or the amount of $\mathrm{H}_{2} \mathrm{O}$ entering the stratosphere through the "cold trap" around the tropical tropopause (Austin et al., 2007; Oman et al., 2008).

Given the variety of commingled influences on the projected future evolution of stratospheric ozone, attribution of changes in ozone to decreases in ODSs resulting from the Montreal Protocol is challenging. As seen from the discussion presented above, a great deal has been learned of how different factors may influence recovery of ozone. Some of these studies have used multiple linear regression of 3-D
Chemistry-Climate Model (CCM) results to apportion cause and effect (e.g., Jonsson et al., 2009; Oman et al., 2010). Other studies have used 2-D models to perform scenario simulations with different forcings alternately held constant or allowed to vary with time (e.g., Brasseur and Hitchman, 1988; Portmann and Solomon, 2007). Owing to their large computational cost, it is only more recently that full 3-D $\mathrm{CCMs}$ have begun to be used to investigate the influence of different factors through similar scenario simulations as used earlier in 2-D modelling studies (e.g., Waugh et al., 2009). However, these previous 3-D CCM scenario studies merged separate simulations for the past (using observed Sea-Surface Temperature - SST - and sea ice fields) and future (modelled SST/sea ice) periods. Here we present three different scenario simulations, each based on an ensemble of three runs, performed with the Canadian Middle Atmosphere Model (CMAM) coupled to a 3-D interactive ocean and run continuously for 1950-2100 to explore the role of climate change and ODSs on the evolution of stratospheric ozone.

\section{Model and experiments}

The CMAM is built on the CCCma third generation atmospheric general circulation model (Scinocca et al., 2008). The model employs a spectral dynamical core with triangular truncation at total wavenumber 31 (T31) and 71 model levels in the vertical, with a lid at approximately $95 \mathrm{~km}$ for these simulations. The representation of stratospheric chemistry includes the important $\mathrm{O}_{\mathrm{x}}, \mathrm{HO}_{\mathrm{x}}, \mathrm{NO}_{\mathrm{x}}, \mathrm{ClO}_{\mathrm{x}}$ and $\mathrm{BrO}_{\mathrm{x}}$ catalytic cycles controlling ozone in the stratosphere, as well as the chemistry of long-lived source gases such as $\mathrm{CH}_{4}, \mathrm{~N}_{2} \mathrm{O}$ and several halocarbons (de Grandpré et al., 1997). Chemical species, families or individual species where required, are advected using spectral advection. Heterogeneous reactions are included on sulphate aerosols, liquid ternary solution (PSC type Ib) and water ice (PSC type II) particles. No sedimentation is allowed for these particles, with the material sequestered in the aerosol phase returning to the gas-phase when environmental conditions can no longer maintain equilibrium with the aerosol phase. Note that the model does not contain a parameterization of Nitric Acid Trihydrate (NAT) PSCs or associated denitrification.

The CMAM has been part of a multi-model intercomparison performed under the Chemistry-Climate Model Validation (CCMVal) activity. As part of CCMVal, participating models performed a set of defined simulations with prescribed forcings and results were compared with a range of available observations of chemical and dynamical fields over the recent past. The comparisons performed under CCMVal have shown CMAM to be one of the better performing models (Eyring et al., 2006; Waugh and Eyring, 2008). Additionally, the general climatology of CMAM has also been assessed as a part of a number of individual studies (e.g., Fomichev et al., 2007; McLandress and Shepherd, 
2009), while particular aspects of the model have been tested in more targeted comparisons (e.g., Hegglin and Shepherd, 2007). Given the extensive assessment of CMAM performed previously, comparisons of CMAM with observations are limited here. For more information on the performance of CMAM as compared with observations the reader is referred to the articles mentioned above, the CCMVal report (SPARC CCMVal, 2010), as well as an upcoming special issue of CCMVal-2 papers in the Journal of Geophysical Research.

All of the simulations presented here were coupled to an Ocean General Circulation Model (OGCM) based on a modified (Arora et al., 2009) version of the National Center for Atmospheric Research community ocean model (NCOM 1.3) (Gent et al., 1998). The OGCM employs the same land/sea mask as the atmospheric model and is specified to have nine ocean grid boxes within each atmospheric grid box, giving a horizontal resolution of approximately 1.9 degrees. The ocean model has 29 vertical levels with a $50 \mathrm{~m}$ upper layer and $300 \mathrm{~m}$ layers in the deep ocean.

\subsection{Description of experiments}

To explore the effects of long-lived Greenhouse Gases (GHGs) and ODSs on the evolution of stratospheric ozone three different experiments were run, each with three ensemble members covering the period 19502100. The first experiment follows the Chemistry Climate Model Validation (CCMVal-2) specifications for what is referred to as the REF-B2 experiment (Eyring et al., 2008) with time-evolving concentrations of GHGs and ODSs. The long-lived GHGs follow the moderate SRES A1B scenario (IPCC, 2000), with $\mathrm{CO}_{2}$ specified to increase to 700 ppmv by $2100, \mathrm{CH}_{4}$ peaking at $2.4 \mathrm{ppmv}$ at mid-century then declining to $2.0 \mathrm{ppmv}$ and $\mathrm{N}_{2} \mathrm{O}$ increasing steadily to $370 \mathrm{ppbv}$ at 2100 . The specified lower boundary conditions for the halocarbons follow the A1 scenario (WMO, 2007), with a lower boundary condition for total organic chlorine increasing rapidly from $0.66 \mathrm{ppbv}$ in 1950 to a peak of $3.6 \mathrm{ppbv}$ in the early $1990 \mathrm{~s}$, then decreasing to $1.3 \mathrm{ppbv}$ near 2100. Total organic bromine is specified to increase from $7.0 \mathrm{pptv}$ in 1950 to $16.7 \mathrm{pptv}$ in the late $1990 \mathrm{~s}$, then return to 8.3 pptv by 2100 .

It is important to note that the radiation scheme in CMAM acts on only a single, prescribed, global average concentration for each long-lived GHG, including $\mathrm{CH}_{4}, \mathrm{~N}_{2} \mathrm{O}$, CFC11 and CFC-12. The chemistry, on the other hand, acts on prognostic tracer concentrations, the spatial distribution of which reflects the effects of physical and chemical processes in the model and which may be forced at the surface by a prescribed concentration. While the specification of spatially uniform concentrations of long-lived GHGs in the radiation represents some inconsistency between radiative and chemical processes in the model, it also allows for the radiative and chemical effects to be easily separated by independently specifying the prescribed concentration passed to the radi- ation and the prescribed boundary condition that forces the chemical tracers. This flexibility has been used for the second and third experiments described below.

In the second experiment, the concentration of the longlived GHGs (including CFC-11 and CFC-12) passed to the radiation evolves following the same $\mathrm{A} 1 \mathrm{~B}$ scenario as the REF-B2 experiment. The lower boundary conditions for the halocarbon chemical tracers, however, are held constant at tropospheric concentrations for the year 1960. This experiment will be referred to below as the "GHG" simulation, to denote a simulation with evolving GHG forcing.

In the third experiment, the halocarbon chemical tracers are forced by the same time evolving tropospheric boundary condition as the REF-B2 experiment, while the specified GHG concentrations passed to the radiation are held at 1960 values. This experiment will be referred to as the "CHM" simulation below, as we use the results from this experiment to explore the effects of chemistry on the results, particularly the interaction of chemical processes with radiative forcing. Note that for the CHM simulation the concentrations of the chemical $\mathrm{CH}_{4}$ and $\mathrm{N}_{2} \mathrm{O}$ tracers are specified with a time evolving lower boundary condition that is identical to that used in the REF-B2 experiment (SRES A1B scenario), while being held constant at 1960 concentrations for the radiation.

Following the standard specification of climate change type simulations within the CCMVal activity, other external forcings were ignored. There are, therefore, no eruptive volcanoes or solar cycle effects included in these simulations. All simulations were begun from an initial ocean state taken from an 1850 control run of the standard CCCma CGCM. To reduce computational cost and save time a single coupled simulation of dynamical CMAM, a version of the model without chemistry and using a specified ozone distribution, was run forward with evolving GHG concentrations to 1950 . At 1950 a set of three simulations was launched using randomly perturbed atmospheric states. This first set of simulations was found to be biased cold in the troposphere by approximately $0.5 \mathrm{~K}$ globally for present-day conditions and some minor model retuning was performed. The retuned version was used for the simulations presented here, with initial ocean states at 1950 taken from the year 2000 of the three initial simulations to provide a tropospheric climate representative of 1950. All simulations were begun in the year 1950 using the initial ocean state derived as described and the first ten years of the simulations were discarded, allowing some time for the chemical state of the atmosphere to "spin up". To check whether this procedure might have introduced any transient artifacts, we examined the global average lower troposphere temperature over the period 1960-1979 in the constant GHG simulation (CHM) and could detect no trend, confirming the stable climate of the coupled system.

These different experiments are analyzed to demonstrate the effects of ODSs on ozone and temperature. Following Waugh et al. (2009), we define the effect of ODSs on the reference REF-B2 simulation as the difference between REF- 

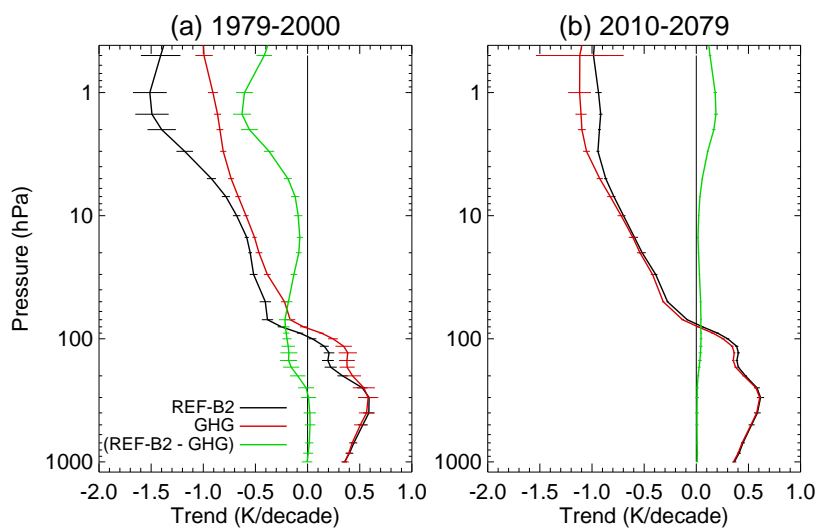

Fig. 1. Linear trends in global annual average temperature over the periods 1979-2000 (a) and 2010-2079 (b). Trends were calculated from ensemble averages of the REF-B2 (black line) and GHG runs (red line). The trend attributed to ODSs, derived as (REF-B2GHG), is given by the green line. The $95 \%$ confidence intervals of the trends are given by the horizontal bars.

B2 and the simulation with ODSs held constant at 1960 values (the GHG simulation). The CHM simulation, with evolving ODSs and constant radiative forcing, is explored separately for the effects of long-term changes in the B-D circulation and $\mathrm{CO}_{2}$ cooling on the chemistry of the stratosphere.

Note that the set of scenario runs analyzed have been submitted to the CCMVal-2 model intercomparison and form part of the multi-model ensemble of scenario runs presented in Eyring et al. (2010).

\section{Results}

We begin with vertical profiles of trends in the global-average temperature from the different experiments shown in Fig. 1. The trends are presented for two time periods; for 19792000, when the concentration of ODSs was rising rapidly, and for the period 2010-2079 during which the concentration of ODSs was more slowly decreasing. The trends are calculated using least-squares estimation based on annual average temperatures of the ensemble mean of each experiment. The 95\% confidence interval of the trend, accounting for autocorrelation in the time series using the "adjusted standard error" method of Santer et al. (2000), is given by the horizontal bars on each vertical profile. The effects of ODSs on temperature are calculated by creating an annual time series of the differences between the ensemble means of the REF-B2 and GHG simulations and calculating trends from this data.

First, we note that the temperature trends of the REF-B2 and GHG runs are statistically identical through much of the troposphere for both time periods. This is as expected, since the radiative forcing from the long-lived GHGs for these two runs was constructed to be identical. Differences are found in the 1979-2000 global average trends between 200 and
$100 \mathrm{hPa}$, reflecting the effects of stratospheric ozone depletion on temperature in the lowermost extra-tropical stratosphere in the REF-B2 runs. Above the tropopause, given that globally averaged the stratosphere is close to radiative equilibrium, the global temperature trends shown in Fig. 1 largely reflect the effects of changing concentrations of radiatively active species. For the 1979-2000 time period the REF-B2 simulation reproduces the main features of the observed temperature trends over the recent past, with negative temperature trends throughout the stratosphere generally increasing with height and a maximum cooling of $1.5 \mathrm{~K} /$ decade around the stratopause (Randel et al., 2009). We note that the REF-B2 cooling trends for the recent past presented here are slightly larger than those shown for CMAM in Eyring et al. (2007), particularly through the mid- to upper-stratosphere, as an interpolation error in the $\mathrm{CO}_{2}$ cooling parameterization has been recently corrected (Jonsson et al., 2009).

The effect of ODSs on temperature is given by the trend in the difference (REF-B2-GHG) and is shown by the green line in Fig. 1. For the 1979-2000 period shown in panel a, the effect of ODSs on temperature is large in the lower stratosphere, comes to a minimum around 10 to $20 \mathrm{hPa}$, then increases in the upper stratosphere. This pattern in the vertical distribution of differences in the temperature trends is a reflection of the differences in ozone changes between these two runs (see below) and approximates the expected pattern of halogen-driven ozone loss (e.g., WMO, 2007). Further, we find that temperature trends in the REF-B2 and GHG experiments are statistically identical in the tropics $\left(22^{\circ} \mathrm{S}\right.$ to $22^{\circ} \mathrm{N}$ ) at all levels below $20 \mathrm{hPa}$ (not shown), showing that the effects of ODSs on global average temperature trends in the lower to mid-stratosphere are due to ozone changes at extra-tropical latitudes. This is a reflection of the fact that halogens play a relatively minor role in the chemistry of the tropical lower to mid stratosphere.

Cooling in the upper stratosphere is largely a result of decreases in ozone, decreasing the shortwave heating by ozone, and increases in longwave cooling from increasing $\mathrm{CO}_{2}$ (Shine et al., 2003). Comparing temperature trends of the REF-B2 and GHG simulations, we find that for the 19792000 period $\mathrm{CO}_{2}$, with a small additional contribution from increasing $\mathrm{H}_{2} \mathrm{O}$, contributes a minimum of $60 \%$ of the total cooling found in REF-B2 at the stratopause, with larger contributions above and below. The $\mathrm{CO}_{2}$ contribution to cooling defined in this manner implicitly includes a reduction of the cooling by the response of ozone to lower temperatures in this region. Following the argument of Shepherd and Jonsson (2008) that ozone is an internal property of the atmosphere, the cooling rate from $\mathrm{CO}_{2}$ defined in this manner would then be the most accurate estimate of the total effect of $\mathrm{CO}_{2}$ on temperature trends in the upper stratosphere. Here, we estimate that ozone decreases from ODSs contribute up to $40 \%$ of the total cooling in the REF-B2 experiment, derived from the temperature trend of the difference (REF-B2-GHG). As before, this estimate would include some degree of mitiga- 

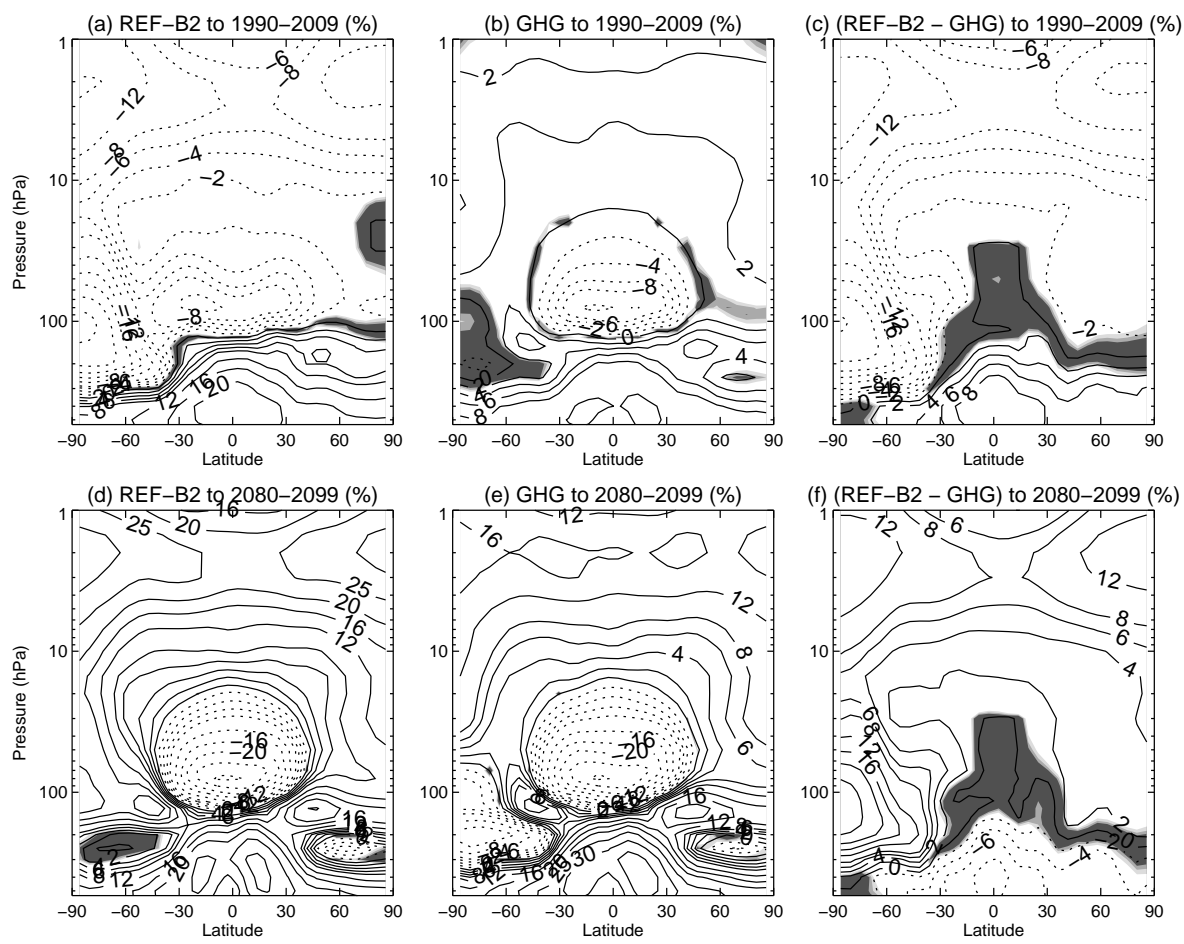

Fig. 2. The change in the zonal annual average ozone mixing ratio from 1960-1974 to 1990-2009 (top row) and the change from 1990-2009 to 2080-2099 (bottom row) for REF-B2, GHG and (REF-B2-GHG). All changes are expressed as percentages of the 1960-1974 average. Shading denotes regions where the differences are not statistically significant at the 98, 95 and $90 \%$ level as deduced from the student's t-test accounting for lag-1 autocorrelation.

tion of the cooling from ODSs due to the internal response of ozone to additional cooling.

These results are broadly in agreement with previous estimates of the relative contribution of ozone depletion and $\mathrm{CO}_{2}$ cooling to the upper stratospheric temperature trends (Shine et al., 2003; Jonsson et al., 2009). The exact contribution assigned to ODSs will be sensitive to the magnitude of ozone depletion in the model, though the decrease of ozone in these CMAM REF-B2 experiments is roughly in agreement with observations in the mid to upper stratosphere (Jonsson et al., 2009). We further note that these results are sensitive to the exact period over which the trends are calculated, with the ODS contribution approaching $50 \%$ at $1.5 \mathrm{hPa}$ when the trends are calculated over 1975-1995, for example, avoiding the late 1990s when the rate of increase of halogens in the upper stratosphere slowed markedly.

Temperature trends for the future period (panel $b$ ) show the dominant effect of increasing concentrations of $\mathrm{CO}_{2}$ through the 21 st century. The recovery of ozone from halogens will take place at a much slower rate than the rapid depletion that occurred between 1980 and 2000 (e.g., Eyring et al., 2007) and we find that global temperature trends attributed to ozone recovery from ODSs are correspondingly smaller. For the period 2010-2079, temperature trends in the REF-B2 simulation are very similar to those in the GHG runs, where halocarbon concentrations were held constant at $1960 \mathrm{lev}$ els. The results show a small warming trend due to ozone increases from decreasing halogens in the lower stratosphere and a larger trend from approximately 5 to $1 \mathrm{hPa}$ in the upper stratosphere.

\subsection{Ozone changes: recent past}

Changes of ozone in the recent past, during the period when stratospheric halogen concentrations were rapidly increasing, and during the period to the end of the 21 st century over which ODSs are projected to more slowly decrease, are presented in Fig. 2. Panels a-c of Fig. 2 present zonal crosssections of the absolute change in the annual average ozone mixing ratio between the periods 1960-1974 and 1990-2009 for the REF-B2 and GHG simulations and, as above, the change attributed to ODSs derived from the difference between the two simulations. The bottom three panels present a similar set of plots for changes between the periods 1990 2009 and 2080-2099. All changes are expressed as a percentage of the 1960-1974 average, when the REF-B2 and GHG experiments gave statistically identical distributions of ozone, so that changes can be compared between experiments and between time periods.

For the period 1960-1974 to 1990-2009 the REF-B2 simulation (panel a) shows large decreases in the upper strato- 
sphere, with maximum losses toward the higher latitudes in each hemisphere, and a much smaller decrease in the midstratosphere, generally reproducing the pattern of observed changes in ozone over the recent past (Randel and Wu, 2007). These simulations also show the large observed decreases in the Southern Hemisphere lower stratosphere associated with PSC chemistry and Antarctic ozone depletion. We note one area of disagreement with observations over high latitudes in the Northern Hemisphere lower stratosphere. In this region observations show net changes of -4 to $-8 \%$ from 1979 to 2005 between 50 and $200 \mathrm{hPa}$ (Randel and $\mathrm{Wu}, 2007$ ), while CMAM shows decreases of no more than $2 \%$ with statistically significant increases below $150 \mathrm{hPa}$. As noted above, CMAM does not contain a parameterization of NAT or denitrification and this may be contributing to the underestimation of ozone loss in this region. However, the exact role of NAT in polar heterogeneous chemistry is still uncertain (Drdla et al., 2002) and there remains no clear consensus on how best to parameterize NAT in models (WMO, 2007, Sect. 4.2.2), particularly given the computational constraints of CCMs. Decadal-scale dynamical variability may also have contributed to producing larger apparent trends in the observations, particularly at levels below $18 \mathrm{~km}(\sim 65 \mathrm{hPa})$ (Yang et al., 2006; WMO, 2007, Sect. 3.2.3.2). It is notable, in this respect, that most CCMs examined by CCMVal underpredict the observed Arctic ozone loss by roughly a factor of two (SPARC CCMVal, 2010, chapter 9), lending additional credence to this hypothesis.

Between 1960-1974 and 1990-2009, the REF-B2 simulation produces decreases in ozone across the upper stratosphere of 6 to more than $12 \%$ due, predominantly, to the combined effects of increasing halogens partly offset by cooling, while the GHG simulation with constant concentrations of ODSs produces an increase in ozone of 2 to $3 \%$. As before with temperature trends, we estimate the effects of ODSs on ozone by the difference between the REF-B2 and GHG experiments, shown in panel $\mathrm{c}$ of Fig. 2. The net change in ozone in the REF-B2 experiment is between $65 \%$ (around $10 \mathrm{hPa}$ ) and $85 \%$ (around $1 \mathrm{hPa}$ ) of the change that can be attributed to ODSs (not shown). The decrease in the apparent effect of ODSs on ozone in the REF-B2 simulation is due to increases in ozone due to cooling by $\mathrm{CO}_{2}$, with the magnitude of the effect derived here being roughly in accord with the results from multiple linear regression analysis by Jonsson et al. (2009).

In the tropical lower stratosphere, both the REF-B2 and GHG simulations produce significant decreases in the concentration of ozone. An increase in tropical upwelling is one aspect of the response of the B-D circulation to climate change and is almost unanimously projected to occur by CCMs (Butchart et al., 2006, 2010). The more rapid tropical upwelling results in a decrease in the transport time of ozonepoor air from the troposphere, resulting in decreased ozone concentrations in the lower tropical stratosphere (Waugh et al., 2009; Eyring et al., 2010). The change in ozone found in the model simulations is qualitatively similar to trends seen in observations (Randel and Wu, 2007), though the comparison must be approached with caution. As discussed by Randel and Wu (2007) there remain a number of caveats to the observations of ozone in the lower tropical stratosphere including relatively low ozone concentrations and strong vertical gradients that make satellite observations difficult and the fact the SAGE satellite observations are in geometric height coordinates and may then be affected by geopotential height trends due to tropospheric warming. Further, the observed trends in the zonal mean ozone concentration would also imply decreasing trends in total column ozone, something that is not apparent in the independent observations of total column, unless there are compensating increases in tropospheric ozone (Randel and $\mathrm{Wu}, 2007)$.

Although both the REF-B2 and GHG simulations display similar decreases in ozone in the tropical lower stratosphere related to changes in tropical upwelling, there are notable differences in the Southern Hemisphere that show the effect of ODS-driven ozone depletion at higher latitudes reaching to tropical latitudes. The GHG simulation shows decreases in ozone that extend across almost all latitudes where the residual vertical velocity is positive (approximately $35^{\circ} \mathrm{S}$ to $35^{\circ} \mathrm{N}$ ) in the lower stratosphere, with decreases that are approximately symmetric around the equator. The decrease in ozone in the REF-B2 run displays a local maximum around $20^{\circ} \mathrm{S}$ that results from the equator-ward mixing of ozone depleted air from higher latitudes. The pattern of the differences can be seen more clearly in the (REF-B2-GHG) difference, shown in panel c. Decreases of ozone of 2 to $4 \%$ are found at $70 \mathrm{hPa}$ between 20 and $30^{\circ} \mathrm{S}$, while in the Northern Hemisphere at these latitudes changes in ozone are not statistically significant.

Both the REF-B2 and GHG simulations show significant positive trends in ozone in the troposphere, though these changes must be viewed with caution. These increases are likely related to increases in stratosphere-to-troposphere exchange of ozone with changes in the B-D circulation (Hegglin and Shepherd, 2009). However, the version of CMAM used for these experiments does not calculate chemistry on model levels below $400 \mathrm{hPa}$ and does not contain parameterizations of processes such as ozone precursor emissions or wet deposition or other processes important for tropospheric chemistry and therefore, the magnitude of the response of ozone in the troposphere is likely incorrect.

\subsection{Ozone changes: future}

We now focus on changes from 1990-2009, the period encompassing the peak ODS concentrations, to the end of the 21 st century shown in the lower panels of Figure 2. While cooling from $\mathrm{CO}_{2}$ had only a small effect on ozone in the upper stratosphere up to 1990-2009, cooling from increasing $\mathrm{CO}_{2}$ becomes an important effect driving ozone increases in this region of the atmosphere through the 21 st century. 
More than $50 \%$ of the increase in ozone above $10 \mathrm{hPa}$ found in the REF-B2 run between 1990-2009 and 2080-2099 can be attributed to cooling from $\mathrm{CO}_{2}$, consistent with what was inferred by linear regression in Jonsson et al. (2009). The contribution from ODSs (panel f) is, as would be expected from the temporal evolution of the concentration of ODSs, largely a reversal of the decreases found between 1960-1974 and 1990-2009 shown in panel c. The tropospheric concentration of halocarbons specified for 2080-2099 is similar to that specified for the early 1970 s, therefore not all of the decreases in ozone attributed to ODSs from the 1960-1974 reference period have been recovered by 2080-2099. However, with the additional contribution from $\mathrm{CO}_{2}$ cooling, ozone above $10 \mathrm{hPa}$ in the REF-B2 run is from 5 to $15 \%$ higher in 2080-2099 than the 1960-1974 average.

Throughout the 21st century ozone concentrations in the low latitudes of the lower stratosphere decrease, reflecting the long-term increase in tropical upwelling and a decrease in the time for photochemical ozone production as tropospheric air enters the stratosphere. Maximum decreases of more than 40\% are found in ozone between 1960-1974 and 2080-2099 around $80 \mathrm{hPa}$ in both the REF-B2 and GHG simulations (not shown directly, but the sum of changes shown in panels a and $\mathrm{d}$ for REF-B2). The CMAM results are not unique, as almost all of the CCMs that participated in CCMVal- 1 and provided results to 2050 displayed a similar decrease in ozone in the lower tropical stratosphere by 2050 (Eyring et al., 2007). While many CCMs project a qualitatively similar response of ozone in the lower tropical stratosphere, the magnitude of the response shown by CMAM should be placed in context relative to other CCMs. The annual average tropical upwelling mass flux in these REF-B2 simulations is approximately $8.5 \times 10^{9} \mathrm{~kg} / \mathrm{s}$ at $70 \mathrm{hPa}$ for the year 2000 , which is larger than that produced by many of the CCMVal-1 CCM simulations shown in Butchart et al. (2010). More relevant for changes in ozone, the rate of increase of tropical upwelling at $70 \mathrm{hPa}$ in CMAM is found to be $2.0 \times 10^{7} \mathrm{~kg} / \mathrm{s} /$ year (2.4\%/decade) in the REF-B2 simulations, also at the upper end of estimates from the different CCMs in Butchart et al. (2010). That changes in tropical upwelling are towards the upper end of estimates from different CCMs implies that the trends in tropical ozone shown here are likely towards the upper end of CCM estimates (see also section 9.3.5, SPARC CCMVal (2010)).

We note that the upwelling mass flux is approximately $10 \%$ larger, and the rate of increase of tropical upwelling $60 \%$ larger, in these simulations than in those given by CMAM in previous simulations using specified SSTs for CCMVal-1. The origins of the changes in the residual circulation are not known at this time, but may be related to changes in the tropospheric climate as a result of parameter tuning to achieve radiative balance for coupling to the ocean model.

At higher latitudes in the lower stratosphere, the response of ozone to climate change alone (the GHG experiment in panel e of Fig. 2) shows an asymmetrical response between the hemispheres, with increases between 80 and $200 \mathrm{hPa}$ in the Northern Hemisphere and decreases in the lower stratosphere at high southern latitudes. These changes in ozone follow changes in the residual circulation. As discussed by McLandress and Shepherd (2009), the CMAM response to climate change is to produce an increase in downwelling over the pole in the Northern Hemisphere and a decrease in downwelling over the southern polar cap. For the Northern Hemisphere the increased downwelling produces increases in ozone of between 6 and $15 \%$ in the lowermost stratosphere in the annual average. The absolute change in the ozone mixing ratio from 1990-2009 to 2080-2099 in this region maximizes in early spring (February-March-April) and reaches a minimum in late fall, consistent with an increase in the dynamical buildup of ozone over the winter. The response of the GHG run at high latitudes in the Southern Hemisphere is opposite of that found in the Northern Hemisphere, consistent with the decreased downwelling in the future. Although the seasonal cycle of ozone in the lowermost stratosphere over Antarctica is not as pronounced as over the north polar cap, the largest changes in the GHG run occur similarly in spring with decreases in 2080-2099 maximizing in OctoberNovember. Note as well, the GHG run shows a decrease in ozone centered around $250 \mathrm{hPa}$ and poleward of $50^{\circ} \mathrm{N}$ that is associated with a decrease in the tropopause pressure with climate change (Son et al., 2009). A similar feature is evident in the Southern Hemisphere, though isolating the effects on ozone is more difficult given the general decreases of ozone in the lower stratosphere.

Changes in lower stratospheric ozone also show the effects of the steady decrease in halogen concentrations over the 21 st century. The effect of ODSs on ozone between 19902009 and 2080-2099, derived as the difference between the REF-B2 and GHG simulation and shown in panel $\mathrm{f}$, is largely a reversal of the changes between 1960-1974 and 19902009. Increases in annual mean ozone of more than $20 \%$ at high southern latitudes are attributed to ODSs, with changes in the annual mean driven by increases in ozone of more than 50\% in October-November (not shown). Smaller increases attributed to ODSs are also found in the Northern Hemisphere mid and high latitudes. It is noteworthy that over 2080-2099 average ozone in the REF-B2 and GHG simulations are statistically identical below about $10 \mathrm{hPa}$, except for a region poleward of $60^{\circ} \mathrm{S}$, and extending down to $150 \mathrm{hPa}$, where the REF-B2 run is from $2-4 \%$ lower than the GHG run (not shown).

\subsection{The role of ODSs}

We have defined the difference between the REF-B2 and GHG simulations as the effect of ODSs on ozone in the REF-B2 run. We now assess how well the temporal variation of this difference can be explained by the evolution of the concentration of halogens. Timeseries of the difference 


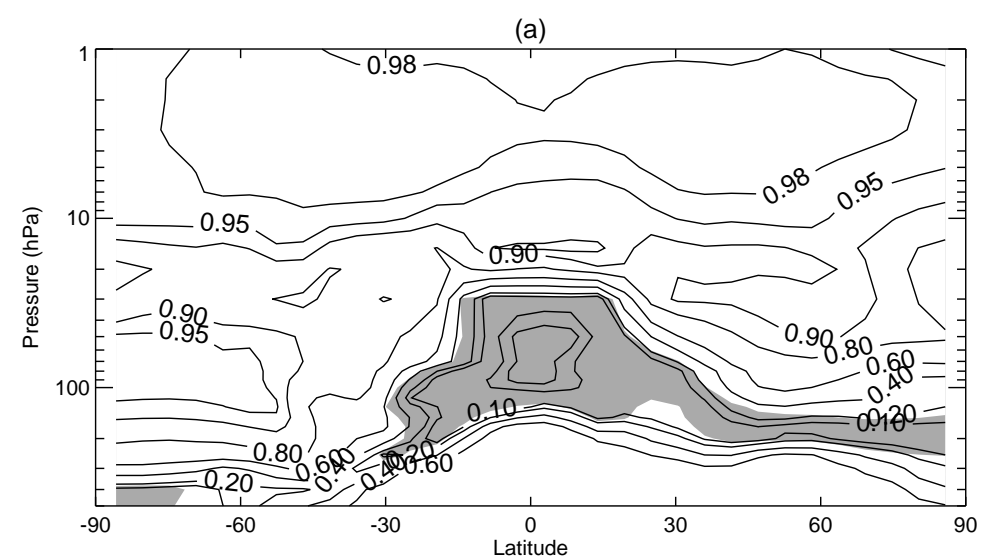

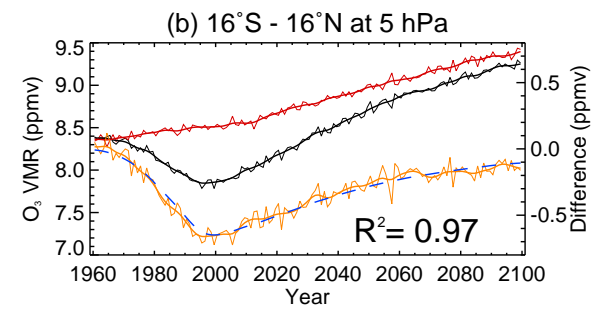

(d) $60-90^{\circ} \mathrm{S}$ at $50 \mathrm{hPa}$

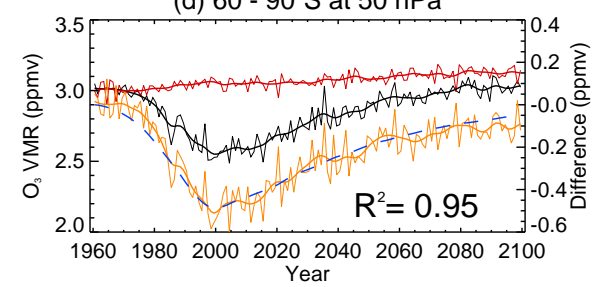

(c) $16^{\circ} \mathrm{S}-16^{\circ} \mathrm{N}$ at $20 \mathrm{hPa}$

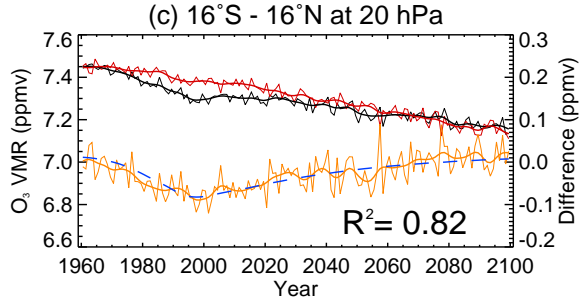

(e) $60-90^{\circ} \mathrm{N}$ at $80 \mathrm{hPa}$

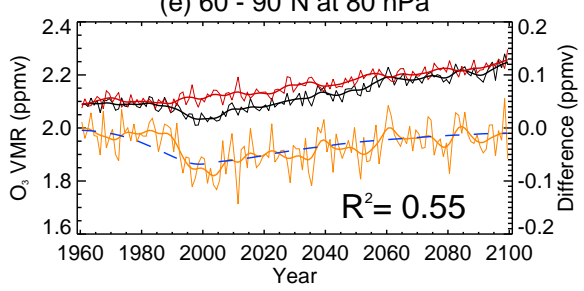

Fig. 3. (a) presents the coefficient of determination from the fit of the smoothed (REF-B2-GHG) ozone timeseries to EESC. Shading denotes regions where the difference between the REF-B2 and GHG runs for 1990-2009 average ozone was not statistically significant at the 95\% level. (b) through (e) present timeseries of the ensemble average ozone mixing ratio from the REF-B2 (black line) and GHG (red line) runs averaged over $16^{\circ} \mathrm{S}-16^{\circ} \mathrm{N}$ at $5 \mathrm{hPa}(\mathbf{b}), 16^{\circ} \mathrm{S}-16^{\circ} \mathrm{N}$ at $20 \mathrm{hPa}(\mathbf{c}), 60-90^{\circ} \mathrm{S}$ at $50 \mathrm{hPa}(\mathbf{d})$ and $60-90^{\circ} \mathrm{N}$ at $80 \mathrm{hPa}(\mathbf{e})$. The orange solid line is the difference (REF-B2-GHG) in ozone and the blue dashed line the result of fitting the difference to the local EESC timeseries. All ozone timeseries display both the original annual averages (thin line) and the series after smoothing with a Gaussian filter with a width of 4 years (thick line).

(REF-B2-GHG) of the monthly and zonally averaged ozone mixing ratio and timeseries of the zonally and monthly averaged Equivalent Effective Stratosphere Chlorine (EESC) have been constructed. Following WMO (2007), EESC is defined as

$\mathrm{EESC}=\left[\mathrm{Cl}_{\mathrm{y}}\right]+60\left[\mathrm{Br}_{\mathrm{y}}\right]$

though here $\left[\mathrm{Cl}_{\mathrm{y}}\right]$ and $\left[\mathrm{Br}_{\mathrm{y}}\right]$ are the model calculated concentrations of total inorganic chlorine and bromine, respectively (note that while no single value of $\alpha$, the coefficient on $\left[\mathrm{Br}_{\mathrm{y}}\right]$, is appropriate throughout the stratosphere, we have performed the following analysis with values of $\alpha$ of 5 and 60 and found the results to be very similar). Both timeseries have been smoothed with a Gaussian filter with a width of 4 years to remove the annual cycle and some of the higher frequency inter-annual variability, and the first and last 10 years of the timeseries were dropped from the analysis to avoid periods where the filter is not fully immersed in the data. The resulting, smoothed (REF-B2-GHG) ozone timeseries for 1970-2089 was then regressed on to the smoothed
EESC timeseries. The coefficient of determination of the regression $\left(R^{2}\right)$ is shown in Fig. 3a and, to delineate regions where ODSs have only small effects on ozone, shading has been added to show regions where the 1990-2010 average ozone in the REF-B2 and GHG runs is not statistically different at the $95 \%$ confidence interval. We find that the timeseries of EESC can account for more than $80 \%$ of the variance $\left(R^{2}>0.8\right)$ in the (REF-B2-GHG) ozone timeseries for the period 1970-2090 over a large part of the atmosphere. The constructed EESC timeseries fits the (REF-B2-GHG) ozone particularly well for the mid to upper stratosphere, where the photochemical lifetime of ozone is short, and over a large part of the Southern Hemisphere stratosphere where the effects of Antarctic ozone depletion are large. The $R^{2}$ values are small in the tropical lower stratosphere, though, as shown by the statistically insignificant differences between the REF-B2 and GHG runs, the effects of halogens on ozone are small here. The only large region where the EESC timeseries accounts for only a small fraction of the variance is in the Northern Hemisphere extra-tropical lower stratosphere, 
below approximately $70 \mathrm{hPa}$, where values of $R^{2}$ are less than 0.6. It should be noted that the exact values of $R^{2}$ are somewhat subjective, in that they depend on the amount of smoothing applied to the ozone timeseries that acts to reduce the contribution of interannual variability to the variance. Using unsmoothed annual averages of the ensemble mean directly yield $R^{2}$ values of greater than 0.8 above $10 \mathrm{hPa}$ and in the Southern Hemisphere lower stratosphere, with values of 0.4 to 0.6 in the Northern Hemisphere middle stratosphere. Here, as we are focusing on the long-term evolution of ozone, the $R^{2}$ values from the smoothed timeseries are preferred.

More details of the EESC fit can be seen in panels b-e of Fig. 3, which present both the original and smoothed timeseries of ozone along with the derived EESC fit for particular regions. In the upper stratosphere the interannual variability is small relative to the ODS perturbation and $R^{2}$ values are quite large, while at high latitudes in the lower stratosphere the interannual variability, even with smoothing, is larger and contributes to variability that cannot be accounted for by the EESC fit and yields lower values of $R^{2}$. In general, however, one can see that the EESC fitting largely follows the long-term evolution of the (REF-B2-GHG) ozone difference - results that are similar to those of Waugh et al. (2009).

Closer inspection of the EESC fit to the (REF-B2-GHG) ozone at high southern latitudes (Fig. 3d) suggests some tendency of the ozone difference to fall below the EESC fit in the latter half of the 21 st century. To analyse how well the EESC fit follows the evolution of ozone in the future, the average residual of the ozone-EESC fit has been calculated for the period 2060-2089 and is shown in Fig. 4 expressed as a percentage of the 2060-2089 average ozone. By definition, the residuals to a least-squares fit should average to zero and we find that is the case over the entire 1970-2089 period for all points (not shown). As can be seen in Fig. 4, we find this also generally holds true over the shorter 2060-2089 period where, accounting for variability, the residuals are not statistically different from zero at even the $90 \%$ confidence level. We do find, however, two regions where the residuals are non-zero. Over the southern polar cap, south of $60^{\circ} \mathrm{S}$ and below approximately $40 \mathrm{hPa}$, the residuals are non-zero at the $98 \%$ confidence level and the EESC fit overestimates ozone by 1 to $3 \%$. A second area in the upper stratosphere, centered around $55^{\circ} \mathrm{S}$ and $4 \mathrm{hPa}$, has average residuals that are non-zero at the $95 \%$ confidence level with the EESC fit underestimating ozone by approximately $0.25 \%$.

The analysis of the residuals of the ozone-EESC fit suggests that ozone in the Southern Hemisphere polar lower stratosphere recovers more slowly than would be indicated by changes in halogens alone. Although we cannot offer any definitive explanation, temperatures in this region of the stratosphere in austral spring have cooled by between 1 and $4 \mathrm{~K}$ in the GHG simulation by the late 21 st century. The small cooling may have increased the efficiency or duration of halogen activation by increasing the prevalence of PSCs, giving rise to slightly more photochemical ozone destruction

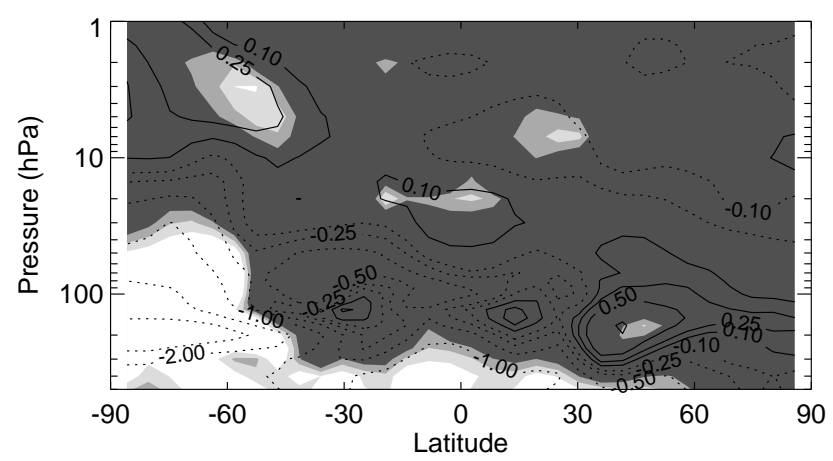

Fig. 4. The average of the residual of the fit of the (REF-B2 - GHG) ozone mixing ratio to EESC over the period 2060-2089, expressed as a percentage of the average ozone mixing ratio over the same time period. The shading indicates regions where the difference of the residual from zero is not statistically significant at the 98,95 and $90 \%$ confidence level. The residual was calculated from the ensemble average annual average ozone mixing ratios (unsmoothed) and the calculation of statistical significance was based on a two-sided t-test accounting for lag-1 autocorrelation.

at comparable EESC levels. Another possibility is the delay in the breakdown of the Antarctic vortex which allows the ozone depleted air within the vortex to remain dynamically isolated for a longer period of time (see McLandress et al., 2010, for a discussion of the effects of ODSs and GHGs on the Antarctic vortex in these simulations).

\subsection{Evolution of ozone under constant GHG forcing}

The third experiment of the set was run with specified greenhouse gas radiative forcing held constant at 1960 levels and tropospheric halocarbon concentrations that evolved following the standard WMO A1 scenario used in the REF-B2 experiment. This experiment, the CHM run, has not been discussed so far as the concentrations of chemical $\mathrm{N}_{2} \mathrm{O}$ and $\mathrm{CH}_{4}$ (distinct from the radiative effects of these species) evolved as in the REF-B2 experiment and complicate the interpretation of the effects of ODSs on ozone. We analyze results from this experiment briefly here to illustrate other aspects of climate change on stratospheric ozone.

Similar to Fig. 2 above, the change in ozone from 19601974 to 1990-2009 and from 1990-2009 to 2080-2099 from the CHM experiment is shown in Fig. 5. The changes in ozone in the CHM run from 1960-1974 to 1990-2009, the period when ODSs were the dominant forcing, are similar to the effects of ODSs derived as the (REF-B2-GHG) difference shown in Fig. 2. We note the lack of change in ozone in the lower tropical stratosphere is consistent with the constant tropospheric climate forcing and a constant B-D circulation. We do find an increase in tropical upwelling in the CHM run for the period 1975-2000 associated with Antarctic ozone depletion (Li et al., 2008; McLandress and Shepherd, 2009). The positive trend in upwelling mass flux is, 


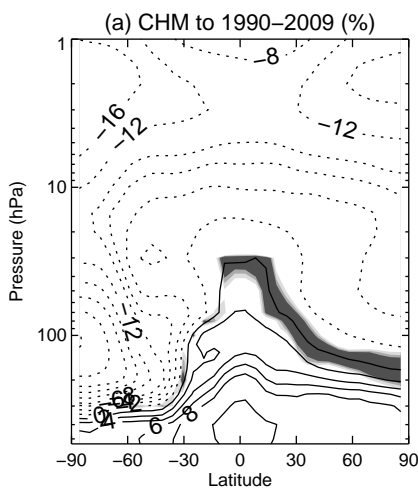

(b) $\mathrm{CHM}$ to $2080-2099(\%)$

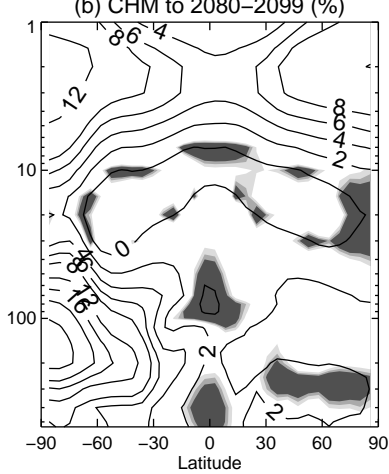

Fig. 5. The net change in the ozone mixing ratio from the CHM experiment from 1960-1974 to 1990-2009 (a) and from 1990-2009 to 2080-2099 (b). As in Fig. 2, the change is expressed as a percentage of the 1960-1974 average and can be directly compared to the results of the REF-B2 and GHG run shown in Fig. 2.

however, limited to the DJF season and is approximately onehalf the rate of increase in the REF-B2 simulation. Trends in other seasons in the CHM simulation are not statistically different from zero. We find that the limited increase in tropical upwelling associated with ozone depletion is not sufficient to induce significant changes in annual average ozone in the lower tropical stratosphere, a finding that is consistent with the differences between the REF-B2 and GHG simulations shown above and the relatively small changes in age of air in the CHM simulation in this same region (not shown). We note the absence of a noticeable effect on lower stratospheric tropical ozone is contrary to that found by Waugh et al. (2009), who show an effect of Antarctic ozone depletion on annual average ozone in the lower tropical stratosphere that is related to changes in tropical upwelling.

Changes in ozone over the 21 st century, as the concentration of ODSs decline, are shown in Fig. 5b. The recovery of ozone in the upper stratosphere in the CHM simulation shows the same general pattern as found in the (REF-B2GHG) estimate of the effect of ODSs, however the increases are generally smaller. More strikingly, the CHM simulation shows a continued small net decrease in the mid-stratosphere after the peak in ODSs around the year 2000. The behaviour can be more clearly seen by looking at time series of ozone concentrations from the three experiments. Panel a of Fig. 6 presents the smoothed, ensemble average ozone concentrations averaged from $60^{\circ} \mathrm{S}$ to $60^{\circ} \mathrm{N}$ at $10 \mathrm{hPa}$ for the REFB2, GHG and CHM experiments. As discussed above, the GHG experiment, shown by the red line, shows a continual increase in ozone throughout the length of the experiments as the increasing concentration of $\mathrm{CO}_{2}$ produces a long-term decrease in temperature. Both the REF-B2 and CHM runs display the effects of the peak in halogen concentrations around the year 2000. The REF-B2 run recovers as halogen concentrations decrease. In fact, with the additional increase in ozone from $\mathrm{CO}_{2}$-driven cooling the concentra-

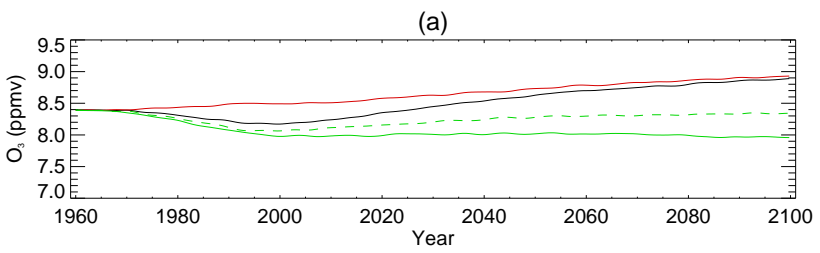

(b)

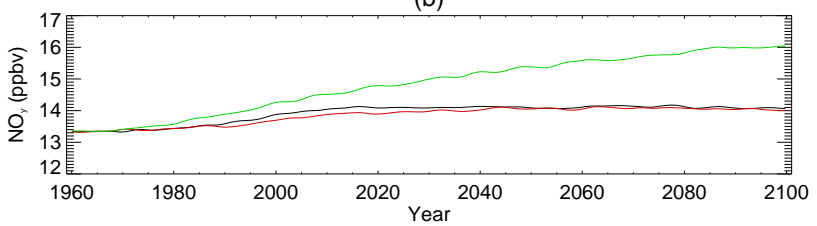

(c)

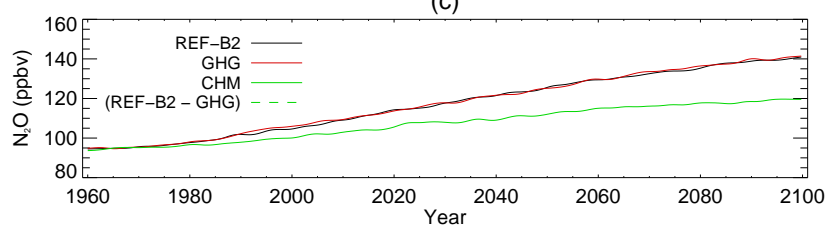

Fig. 6. Time series of the concentrations of $\mathrm{O}_{3}(\mathbf{a})$, total reactive nitrogen, $\mathrm{NO}_{\mathrm{y}}(\mathbf{b})$ and $\mathrm{N}_{2} \mathrm{O}$ (c) from the REF-B2 (black line), GHG (red line) and CHM (green line) experiments. The concentrations are ensemble averages from $60^{\circ} \mathrm{S}$ to $60^{\circ} \mathrm{N}$ at $10 \mathrm{hPa}$ and have been deseasonalized by fitting an 8 term sinusoidal to the monthly averages and smoothed with a Gaussian filter with a width of four years. The first panel also includes the estimate of the ODS effect on ozone derived as (REF-B2-GHG), with the addition of the 1960-1974 average from the REF-B2 experiment (green dashed line).

tion of ozone in the REF-B2 run at $10 \mathrm{hPa}$ returns to 1980 values around 2020, though halogens do not decrease back to 1980 values here until 2050. Ozone in the CHM run, having constant $\mathrm{CO}_{2}$ concentrations, will not be affected by the $\mathrm{CO}_{2}$-driven cooling in the mid- to upper stratosphere. There are, however, clearly other effects at work as the concentration of ozone in the CHM run remains well below 1980 values out to 2100 , even as halogens return to concentrations found in the mid-1970s. Also shown in panel a is the (REFB2-GHG) ozone timeseries that, as discussed above, closely follows the concentration of halogens. The ozone timeseries from the CHM experiment steadily diverges from the derived (REF-B2-GHG) timeseries, with small differences apparent as early as the year 2000 .

\subsubsection{Interactions of nitrogen compounds with GHG-induced changes}

The dominant effect explaining the different evolution of ozone in the CHM experiment is the increase in total reactive nitrogen $\left(\mathrm{NO}_{\mathrm{y}}\right)$, shown in panel $\mathrm{b}$ of Fig. 6, with $\mathrm{NO}_{\mathrm{y}}$ concentrations $14 \%$ higher over $2080-2099$ at $10 \mathrm{hPa}$ than in the REF-B2 or GHG simulations. Note that the differences between the simulations for $\mathrm{NO}_{\mathrm{x}}\left(\mathrm{NO}+\mathrm{NO}_{2}\right)$ are almost identical (13.6\%) (not shown). Recalling that all three experiments used identical lower boundary conditions for the chemical $\mathrm{CH}_{4}$ and $\mathrm{N}_{2} \mathrm{O}$, independent of the radiative effects of these species, the different reactive nitrogen in the CHM experiment results from interactions of $\mathrm{N}_{2} \mathrm{O}$ and reactive 
nitrogen compounds with GHG-induced changes. The interactions of changing GHGs and $\mathrm{N}_{2} \mathrm{O}$ have been extensively explored with two-dimensional models (Rosenfield and Douglass, 1998; Randeniya et al., 2003; Chipperfield and Feng, 2003). We provide an analysis of the effects here both as an update of the previous studies with a full 3-D CCM, as well as to underline and quantify one other way in which the effects of climate change have been implicitly included in the REF-B2 results.

One aspect of these interactions is illustrated in panel c of Fig. 6, which shows the time series of modelled $\mathrm{N}_{2} \mathrm{O}$ at 10 hPa. From 1960-1974 to 2080-2099 the tropospheric concentration of $\mathrm{N}_{2} \mathrm{O}$ is specified to increase by $24.7 \%$ in the A1B scenario used here. The concentration of $\mathrm{N}_{2} \mathrm{O}$ at $10 \mathrm{hPa}$ in the CHM simulation closely follows the tropospheric change, increasing by $25.0 \%$. However, the concentration of $\mathrm{N}_{2} \mathrm{O}$ in the REF-B2 and GHG simulations increases by $45.8 \%$ over the same time. The more rapid increase of $\mathrm{N}_{2} \mathrm{O}$ is a result of the faster B-D circulation in these two experiments, producing a more rapid transport of air from the troposphere and less time for the photochemical decay of $\mathrm{N}_{2} \mathrm{O}$. A lower concentration of reactive nitrogen, produced as one product of the decay of $\mathrm{N}_{2} \mathrm{O}$, is a result.

The rate of decay of $\mathrm{N}_{2} \mathrm{O}$ may also have changed between these simulations and may contribute to the observed changes in $\mathrm{N}_{2} \mathrm{O}$. The age of air tracer gave an average age of 4.2 years for all three experiments at $10 \mathrm{hPa}$ for the 1960-1974 period. Given the modelled decay of $\mathrm{N}_{2} \mathrm{O}$ from $295 \mathrm{ppbv}$ in the troposphere to $95.1 \mathrm{ppbv}$ at $10 \mathrm{hPa}$, a stratospheric lifetime of 3.7 years can be derived assuming a firstorder decay. By 2080-2099, the average age of air at $10 \mathrm{hPa}$ in the REF-B2 and GHG runs has decreased to 3.2 years and, using the previously derived lifetime, would translate to a $\mathrm{N}_{2} \mathrm{O}$ concentration at $10 \mathrm{hPa}$ of $155 \mathrm{ppbv}$ taking into account the increased tropospheric $\mathrm{N}_{2} \mathrm{O}$ concentration. The modelled $\mathrm{N}_{2} \mathrm{O}$ concentration at $10 \mathrm{hPa}$ of 139 ppbv suggests that the stratospheric lifetime of $\mathrm{N}_{2} \mathrm{O}$ has, in fact, decreased (3.3 years) in the REF-B2 and GHG experiments. Therefore, the increase in the concentration of $\mathrm{N}_{2} \mathrm{O}$ with changes in the $\mathrm{B}-\mathrm{D}$ circulation would have been larger based on changes in the average age of air and are, in fact, moderated by a decrease in the stratospheric lifetime. The decrease in lifetime is, to first-order, most likely related to a more rapid vertical transport of $\mathrm{N}_{2} \mathrm{O}$ to higher levels in the stratosphere where the photochemical lifetime is shorter.

It is worth noting that with a faster B-D circulation the atmospheric lifetime of $\mathrm{N}_{2} \mathrm{O}$ should decrease and, assuming identical emissions, result in lower tropospheric $\mathrm{N}_{2} \mathrm{O}$ concentrations. The use of a specified concentration as a lower boundary condition (as currently used, to the best of our knowledge, by all CCMs for long-lived trace gases) will artificially constrain the simulation. A similar constraint arises for the halocarbons. The effects on model simulations of removing this constraint, by specifying fluxes in place of concentrations at the lower boundary, is not known.

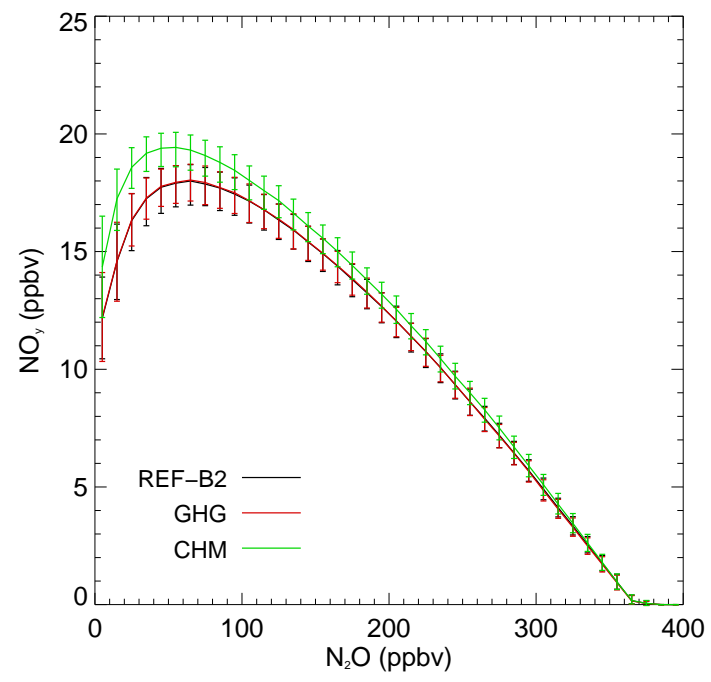

Fig. 7. The relationship between instantaneous concentrations of $\mathrm{N}_{2} \mathrm{O}$ and reactive nitrogen $\left(\mathrm{NO}_{\mathrm{y}}\right)$ between approximately 150 and $1.0 \mathrm{hPa}$ and $15^{\circ} \mathrm{S}$ to $15^{\circ} \mathrm{N}$ for the years 2080 and 2083. Data is taken from one member from each of the three experiments, sampled three times a month, and has been binned according to $\mathrm{N}_{2} \mathrm{O}$ concentration. Each data point shows the mean concentration of $\mathrm{NO}_{\mathrm{y}}$ in each bin, with the vertical bars giving the 10th and 90th percentiles.

From the earlier 2-D modelling studies it is also well recognized that the cooling of the upper stratosphere by increased $\mathrm{CO}_{2}$ has important effects on atomic nitrogen and, by extension, the photochemical loss of $\mathrm{NO}_{\mathrm{y}}$. Cooling in the upper stratosphere will slow the rate of the strongly temperature dependent reaction

$\mathrm{N}+\mathrm{O}_{2} \rightarrow \mathrm{NO}+\mathrm{O}$.

While the slowing of the rate of this reaction will have no net effect on $\mathrm{NO}_{\mathrm{y}}$, it will increase the concentration of atomic $\mathrm{N}$ while having only a very minor effect on the (much larger) concentration of NO. The net effect of the changes will be to increase the rate of loss of $\mathrm{NO}_{\mathrm{y}}$ through the reaction

$\mathrm{N}+\mathrm{NO} \rightarrow \mathrm{N}_{2}+\mathrm{O}$.

The effects of changes in temperature on reactive nitrogen can be seen in Fig. 7, which presents the instantaneous concentration of $\mathrm{NO}_{\mathrm{y}}$ as a function of $\mathrm{N}_{2} \mathrm{O}$ around the year 2080. The two experiments with increasing $\mathrm{CO}_{2}$ show lower concentrations of $\mathrm{NO}_{\mathrm{y}}$ at the same concentration of $\mathrm{N}_{2} \mathrm{O}$ than does the CHM experiment with constant $\mathrm{CO}_{2}$. The differences are largest at $\mathrm{N}_{2} \mathrm{O}$ concentrations less than $100 \mathrm{ppbv}$, which occur in the mid to upper stratosphere where $\mathrm{NO}_{\mathrm{x}}$ catalytic cycles are a particularly important component of the ozone chemistry. For the time period 2080-2099, we find that above approximately $10 \mathrm{hPa}$ the concentration of atomic $\mathrm{N}$ (zonally averaged over all hours) is larger in the REF-B2 and GHG experiments than in the CHM experiment, 

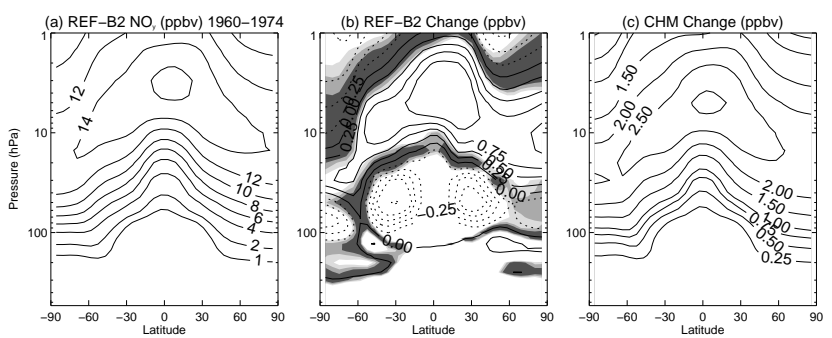

Fig. 8. The zonal average distribution of total reactive nitrogen $\left(\mathrm{NO}_{\mathrm{y}}\right)$ in the REF-B2 experiment averaged over 1960-1974 (a) along with the change in the zonal average concentration of $\mathrm{NO}_{\mathrm{y}}$ between 1960-1974 and 2080-2099 in the REF-B2 (b) and CHM experiments (c). All panels are expressed in ppbv. Note that all three experiments had a very similar distribution of $\mathrm{NO}_{\mathrm{y}}$ over the 1960-1974 period and that the changes in the GHG simulation are very similar to those shown for the REF-B2 experiment in (b).

with the differences increasing to $25 \%$ near the stratopause (not shown). The cooler stratospheric temperatures resulting from increased $\mathrm{CO}_{2}$ give an increase in the concentration of atomic $\mathrm{N}$ and lower concentrations of reactive nitrogen through an increase in the loss rate of $\mathrm{NO}_{\mathrm{y}}$.

The net effect of changes in the B-D circulation and the chemistry on the distribution of reactive nitrogen is shown in Fig. 8. Panel a shows the zonal average concentration of $\mathrm{NO}_{\mathrm{y}}$ over the period 1960-1974 from the REF-B2 experiment, though the other two experiments show essentially identical distributions over this period. The changes between 19601974 and 2080-2099 for the REF-B2 and CHM experiment are shown in panels $b$ and $c$, respectively. As noted above, the concentration of $\mathrm{N}_{2} \mathrm{O}$ entering the stratosphere has increased by nearly $25 \%$, from 295 to 368 ppbv, between 1960-1974 and 2080-2099, though due to increased tropical upwelling the concentration of $\mathrm{NO}_{\mathrm{y}}$ in the REF-B2 experiment has decreased over much of the stratosphere below $20 \mathrm{hPa}$. Above $20 \mathrm{hPa}$, the region where reactive nitrogen chemistry dominates the ozone loss reactions, the REF-B2 experiment shows an increase in $\mathrm{NO}_{\mathrm{y}}$ of between 0.5 and $1.4 \mathrm{ppbv}$. However, without the effects of $\mathrm{CO}_{2}$ cooling on the upper stratosphere and the strengthened B-D circulation the increased $\mathrm{N}_{2} \mathrm{O}$ produces increases in $\mathrm{NO}_{\mathrm{y}}$ that are more than twice as large in the CHM experiment, from 1.5 to $3.0 \mathrm{ppbv}$, over the same region. These results help explain the finding by Oman et al. (2010) that, through multiple linear regression analysis, changes in $\mathrm{NO}_{\mathrm{x}}$ have only a small effect on the future evolution of ozone in simulations with the GEOSCCM model using the same REF-B2 scenario.

\subsection{Column ozone}

By comparing the behaviour of the REF-B2 experiment, which contains the effects of increasing ODSs and GHGs, with simulations where one of these forcings was held constant, we have explored the ways in which these separate (a) $35-60^{\circ} \mathrm{N}$ to $300 \mathrm{hPa}$

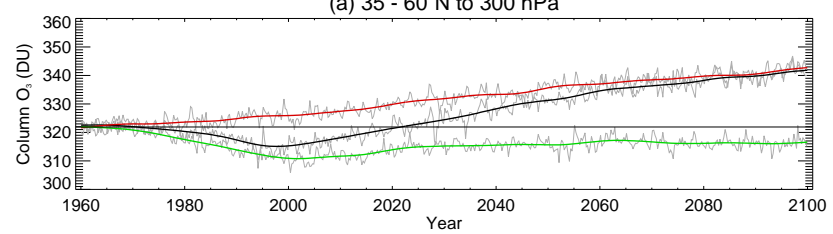

(b) $22^{\circ} \mathrm{N}-22^{\circ} \mathrm{S}$ to $100 \mathrm{hPa}$

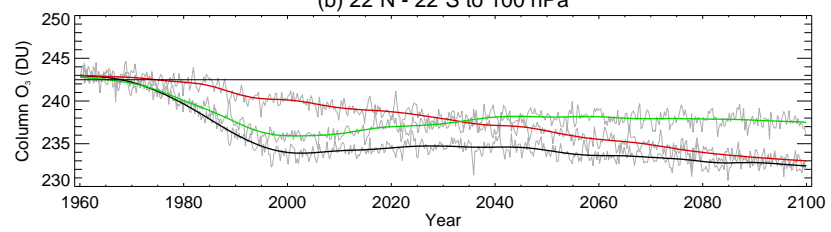

(c) $35-60^{\circ} \mathrm{S}$ to $300 \mathrm{hPa}$

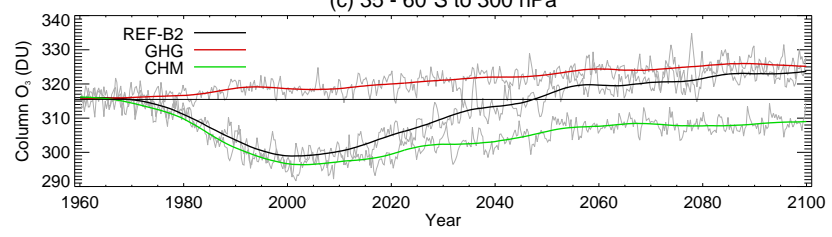

Fig. 9. Time series of ensemble average column ozone from the REF-B2 (black lines), GHG (red lines) and CHM (green lines) experiments over the latitude bands $35-60^{\circ} \mathrm{N}$ (a), $22^{\circ} \mathrm{N}-22^{\circ} \mathrm{S}$ (b) and $35-60^{\circ} \mathrm{S}$ (c). To avoid contributions from the troposphere, the mid-latitude ozone columns are integrated down to $300 \mathrm{hPa}$ and the tropical columns are integrated to $100 \mathrm{hPa}$. The grey lines give the seasonal anomalies from the deseasonalized data and the coloured lines are the data after smoothing by a Gaussian filter with a width of eight years. The black horizontal line shows the 1960-1974 average from the three experiments.

forcings affect stratospheric ozone over the 21 st century. We now look at the net effects on column ozone, the policyrelevant quantity that is directly related to UV radiation levels at the surface. Time series of column ozone amounts for the Northern and Southern Hemisphere mid-latitudes and the tropics are presented in Fig. 9. To avoid including changes in the troposphere, for which we have low confidence, column ozone has been calculated by integrating down to $300 \mathrm{hPa}$ for mid-latitude columns and down to $100 \mathrm{hPa}$ for the tropics. Column ozone in the GHG experiment shows a continual increase over the length of the experiment in the midlatitudes, with a considerably greater increase in the Northern than the Southern Hemisphere, and a steady decrease in the tropics. As was seen above, cooling from increasing $\mathrm{CO}_{2}$ results in an increase in ozone in the mid to upper stratosphere at all latitudes. In the mid-latitudes, the increase in the upper stratosphere is enhanced by further increases in ozone in the lower stratosphere due to changes in ozone transport. In the tropics, the strong decreases in the lower stratosphere resulting from increases in tropical upwelling outweigh increases in the upper stratosphere, resulting in an almost monotonic decrease in column ozone over the length of the GHG experiment. The general features of the evolution of column ozone found here, including a more rapid increase in total column 
ozone over the Northern Hemisphere mid-latitudes than over the Southern Hemisphere mid-latitudes, are consistent with those seen in the suite of CCMVal-2 models (Eyring et al., 2010; SPARC CCMVal, 2010, chapter 9).

As was seen above, the differences between the GHG and REF-B2 experiments are generally well described by the local concentrations of reactive chlorine and bromine and we thus expect the evolution of column ozone to reflect this. For all latitude bands column ozone in the REF-B2 run follows the longer-term trends of the GHG experiment, with the transient effects of ODSs, peaking around the year 2000 and decreasing towards 2100 , superimposed. Recalling that for the GHG experiment the concentration of ODSs was held constant at 1960 values and that ODSs in the REF-B2 run have not completely returned to 1960 values by 2100 , we expect column ozone in the REF-B2 run to remain slightly below that in the GHG experiment at 2100. For the period 20802099, differences in column ozone between the REF-B2 and GHG experiments are statistically significant at more than the $99.5 \%$ confidence interval for the Southern Hemisphere mid-latitudes and the tropics, while the differences over 35$60^{\circ} \mathrm{N}$ are only statistically significant at less than the $80 \%$ level. Comparing the Northern and Southern Hemisphere mid-latitudes, the variance in the annual column is comparable over 2080-2099 and the continued statistical significance of the REF-B2-GHG differences arises primarily from the magnitude of the differences. Earlier, we noted a statistically significant tendency of the (REF-B2-GHG) difference in ozone to lag the trend derived from fitting to EESC in the second half of the 21 st century. Referring back to the average residual of the EESC fit shown in Fig. 3, generally negative ozone residuals are found in the lower stratosphere over the $35-60^{\circ} \mathrm{S}$ latitude band, though most of these are not statistically significant. It is unclear, then, to what extent the continued statistically significant effect of ODSs on Southern Hemisphere mid-latitude column ozone over 2080-2099 is a result of the larger perturbation of column ozone by ODSs in the Southern Hemisphere relative to the Northern Hemisphere and what portion may be related to the tendency of ozone recovery to lag EESC in parts of the Southern Hemisphere.

It has also been shown that reactive nitrogen, driven by increasing concentrations of $\mathrm{N}_{2} \mathrm{O}$, can have significant effects on ozone - particularly in the CHM experiment where circulation and temperature changes do not moderate the effect of increasing $\mathrm{N}_{2} \mathrm{O}$. For all three latitude bands, column ozone in the CHM experiment initially decreases up to the time of the peak in ODS concentrations around the year 2000 . In the absence of perturbations to $\mathrm{NO}_{\mathrm{y}}$ it could be reasonably expected that column ozone would return towards the 1960-1974 baseline as ODSs decrease. In fact, the $\mathrm{N}_{2} \mathrm{O}$ driven increase in $\mathrm{NO}_{\mathrm{y}}$ limits the recovery of column ozone, with little additional increase apparent after 2050 and column ozone at 2100 remaining considerably lower than the 1960-1974 average; an evolution much like that found in the
2-D modelling study of Chipperfield and Feng (2003) using a similar scenario. Estimating the contribution of ODSs to ozone changes in the CHM run from the difference (REF$\mathrm{B} 2-\mathrm{GHG}$ ), the increase in $\mathrm{NO}_{\mathrm{y}}$ (with some additional contribution from $\mathrm{H}_{2} \mathrm{O}$ ) in the CHM run produces a decrease in column ozone of 4.9 DU in both the Northern and Southern Hemisphere mid-latitudes and a decrease of 3.7 DU in the tropics between 1960-1974 and 2080-2099. The effect of changing $\mathrm{NO}_{\mathrm{y}}$ on ozone in the REF-B2 and GHG simulations are likely to be considerably smaller than this estimate as the increase in $\mathrm{NO}_{\mathrm{y}}$ was at most one-half of the increase of $\mathrm{NO}_{\mathrm{y}}$ in the $\mathrm{CHM}$ experiment.

\subsection{Vertical distribution of changes in column ozone}

The vertical distribution of changes in column ozone is now analyzed to separate the contribution of $\mathrm{CO}_{2}$ cooling in the upper stratosphere from changes in the lower stratosphere. The change in ensemble average ozone relative to the 1960 1974 average was integrated from $0.1 \mathrm{hPa}$ downward and is shown in Fig. 10 for the periods 1990-2009 and 2080-2099 for the three latitude bands discussed above, in addition to a near-global average covering $60^{\circ} \mathrm{N}$ to $60^{\circ} \mathrm{S}$. The changes to 1990-2009 (dashed lines) demonstrate the dominant influence of ODSs on ozone, producing decreases in the ozone column above $20 \mathrm{hPa}$ of 5 to $6 \mathrm{DU}$ across the different latitude bands as given by the (REF-B2-GHG) difference. The decrease in column above $20 \mathrm{hPa}$ attributed to ODSs is approximately 30 to $35 \%$ larger than the decrease in ozone found in the REF-B2 simulation alone, as cooling from $\mathrm{CO}_{2}$ has acted to reverse some of the decrease. For the region of the stratosphere below $20 \mathrm{hPa}$, large additional decreases in column are found in the Southern Hemisphere mid-latitudes due to the effects of Antarctic ozone depletion, with a much weaker additional decrease in the Northern Hemisphere midlatitudes. The simulations also demonstrate the effects of changes in the B-D circulation, with tropical ozone (panel c) between 20 and $100 \mathrm{hPa}$ decreasing by $4 \mathrm{DU}$ in the GHG simulation and small increases in the mid-latitude lowermost stratosphere below $100 \mathrm{hPa}$.

The changes to 2080-2099, given by the solid lines in Fig. 10, show that the effects of ODSs on column ozone in the REF-B2 simulation have generally decreased to less than 1-2 DU, reflecting the decreased concentration of halogens. The changes related to $\mathrm{CO}_{2}$ cooling of the upper stratosphere and circulations changes, which were apparent at 19902009, have become the dominant influences on ozone towards the end of the 21st century. Over 2080-2099, both the REF-B2 and GHG experiments show ozone columns above $20 \mathrm{hPa}$ across the different latitude bands are approximately 7-8 DU larger than in 1960-1974 due to cooling of the upper stratosphere. Changes from 1990-2009 to 2080-2099, given by the horizontal shift between the dashed and solid lines, show that the decrease in ODSs has accounted for between 40 and $45 \%$ of the increase in ozone above $20 \mathrm{hPa}$. For both 

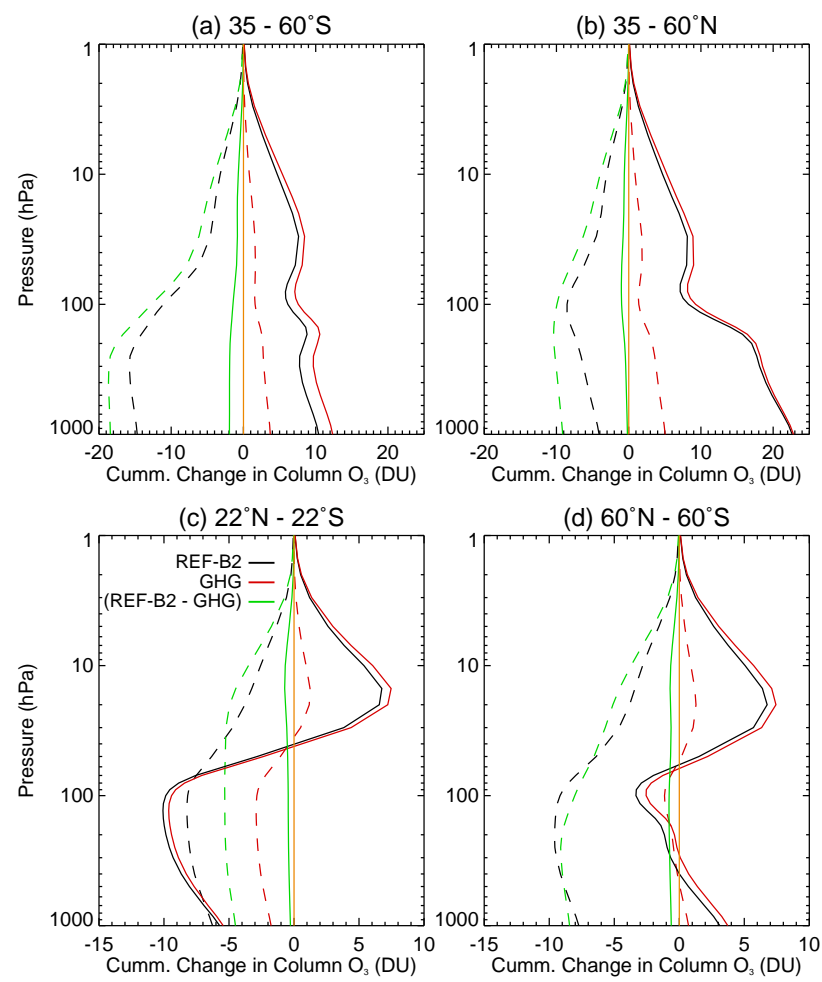

Fig. 10. The vertical integral, from 0.1 hpa downwards, of the change in ozone for the REF-B2 (black) and GHG (red) experiments, along with the effects of ODSs derived as the (REF-B2GHG) difference (green). The changes are relative to the 19601974 average and are shown for 1990-2009 (dashed lines) and 2080-2099 (solid lines) for the latitude bands $35-60^{\circ} \mathrm{S}$ (a), $22^{\circ} \mathrm{N}-$ $22^{\circ} \mathrm{S}(\mathbf{b}), 35-60^{\circ} \mathrm{N}(\mathbf{c})$ and $60^{\circ} \mathrm{N}-60^{\circ} \mathrm{S}(\mathbf{d})$.

the Northern and Southern Hemisphere mid-latitude bands the ozone column shows little net change from $20 \mathrm{hPa}$ down to $90 \mathrm{hPa}$, while between 90 and $300 \mathrm{hPa}$ ozone increases by a further $10 \mathrm{DU}$ in the Northern Hemisphere with only a 2 to $3 \mathrm{DU}$ increase in the Southern Hemisphere. The large increase in ozone in the lowermost stratosphere of the Northern Hemisphere, and the absence of a similar increase in the Southern Hemisphere, accounts for the differences in the evolution of the column ozone between the hemispheres seen above and is related to the changes in the residual circulation discussed above. Although not displayed here, changes in column ozone in the CHM run show only a small increase of 2 to $3 \mathrm{DU}$ in the lowermost stratosphere, consistent with the more stable B-D circulation in the absence of changes in radiative forcing from long-lived GHGs

The contribution of changes in the tropical lower stratosphere can also be quantified from panel c of Fig. 10. As for the mid-latitudes, the column amount of ozone above $20 \mathrm{hPa}$ is approximately 7DU larger in 2080-2099 than in 19601974 in the REF-B2 and GHG experiments. However, the increase in tropical upwelling has reduced ozone between
20 and $100 \mathrm{hPa}$ by approximately $17 \mathrm{DU}$ so that the ozone column at $100 \mathrm{hPa}$ is lower by $10 \mathrm{DU}$ over $2080-2099$. As before, though not shown here, we note that the CHM experiment shows no similar decreases in column ozone over the tropical lower stratosphere.

We now look at the near-global average of the changes in column ozone shown in panel d of Fig. 10. We have seen above that changes in the residual circulation are projected to have significant effects on ozone in certain locations, though by averaging over $60^{\circ} \mathrm{N}$ to $60^{\circ} \mathrm{S}$ the effects of latitudinal transport of ozone by the residual circulation will be largely removed. Focusing on the results from the GHG experiment, which does not contain the additional effects of ODSs, we see that the ozone column above $20 \mathrm{hPa}$ has increased at both 1990-2009 and 2080-2099. Similarly, the ozone between $20 \mathrm{hPa}$ and 200 to $300 \mathrm{hPa}$ has decreased over both time periods. At 2080-2099, the increase above $20 \mathrm{hPa}$ due to $\mathrm{CO}_{2}$ cooling is approximately $7 \mathrm{DU}$ and this is very nearly balanced by decreases through the lower portion of the stratosphere so that column ozone above the tropopause remains little changed. The near-cancellation of changes in the mid to upper stratosphere and the lower stratosphere may be partly a result of "reverse self-healing", where increases in ozone at higher levels in the atmosphere reduce the production of ozone at lower levels through increased absorption of solar radiation. Note that in the doubled $\mathrm{CO}_{2}$ experiments of Fomichev et al. (2007) there was a significant decrease in ozone between about 50 and $20 \mathrm{hPa}$ which could not be accounted for either by circulation changes or by changes in water vapour, so was presumably the result of "reverse self-healing". Additional possible causes of the decrease seen here include changes in the net amount of ozone due to changes in the residual circulation or chemical effects from increased water vapour. Note that stratospheric water vapour has increased by 1.2 to $1.8 \mathrm{ppmv}$ from 1960-1974 to 2080 2099 in the REF-B2 and GHG experiments due both to temperature changes at the cold point and to increased methane.

\subsection{Column ozone: polar regions}

Lastly, we look at polar ozone in the three experiments in Fig. 11, concentrating on the springtime period in each hemisphere when ozone depletion is most significant. The March average ozone over $60-90^{\circ} \mathrm{N}$ shows very similar behaviour to that seen earlier for the annual average ozone in the Northern Hemisphere mid-latitudes: the difference between the REF-B2 and GHG runs displays the effects of ODSs, with the difference losing statistical significance towards the end of the simulation. The average October ozone over the Southern Hemisphere polar cap displays a qualitatively different behaviour, with statistically significant differences between the REF-B2 and GHG runs persisting out to 2100 . We note that the GHG run shows strikingly constant column ozone amounts over the entire 140 years of the simulation, which may be fortuitous as it results from a combination of 
(a) $60-90^{\circ} \mathrm{N}$ to $300 \mathrm{hPa}-$ March

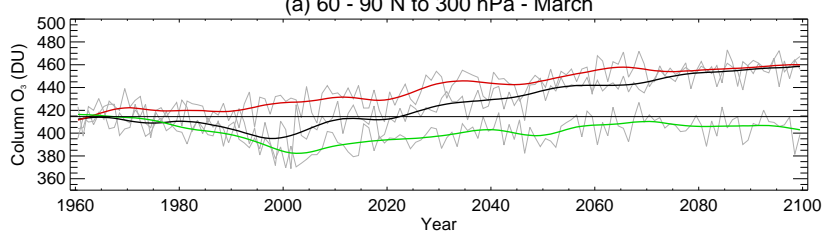

(b) $60-90^{\circ} \mathrm{S}$ to $300 \mathrm{hPa}-$ October

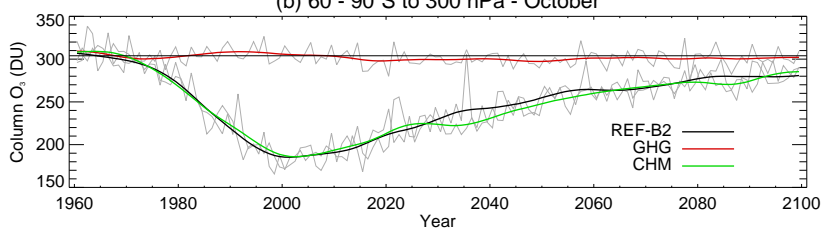

Fig. 11. Time series of ensemble average column ozone for March from $60-90^{\circ} \mathrm{N}$ (a) and October over $60-90^{\circ} \mathrm{S}(\mathbf{b})$. The grey lines show the ensemble average monthly average for each year and the colour lines show the data after smoothing with a Gaussian filter with a width of eight years.

temperature-driven increases in the upper stratosphere and transport related decreases in the lower stratosphere. In a similar vein, the CHM and REF-B2 experiments show a very similar evolution of column ozone though the comparison must be approached with caution since ozone in the CHM experiment is 10 to $20 \%$ lower above $10 \mathrm{hPa}$. This difference in the upper stratosphere is compensated for in the lower stratosphere, where the CHM experiment has ozone that is 10 to $30 \%$ higher than in the REF-B2 experiment between 100 and $200 \mathrm{hPa}$.

\section{Conclusions}

The Canadian Middle Atmosphere Model, a state-of-theart chemistry-climate model coupled to a three-dimensional ocean model, has been used to produce a set of three experiments covering 1950-2100, the period of time during which atmospheric concentrations of Ozone Depleting Substances (ODSs) rise from insubstantial levels, peak and then decline back towards levels where the impacts on ozone are minimal. Concurrent with the rise and fall of ODSs, increasing concentrations of long-lived Greenhouse Gases (GHGs) will have dynamical and chemical effects on the stratosphere. The three experiments use a combination of different radiative forcing from long-lived GHGs and chemical forcing from halocarbons to separate some of the different effects on the evolution of stratospheric ozone. The REF-B2 simulation, the standard future scenario used to project the recovery of ozone in CCMVal and the WMO Ozone Assessment, contains evolving forcings for both the long-lived GHGs (SRES A1B) and the ODSs (WMO A1 scenario). A second experiment, denoted as GHG, used the same evolution of radiative forcing from GHGs and chemical forcing from $\mathrm{CH}_{4}$ and $\mathrm{N}_{2} \mathrm{O}$ as in REF-B2, while keeping ODSs at constant concentrations representative of the year 1960. The third variant, the CHM experiment, kept radiative forcing from the GHGs constant at 1960 levels, while allowing the chemical forcing from $\mathrm{CH}_{4}, \mathrm{~N}_{2} \mathrm{O}$ and ODSs to evolve as in the REF-B2 simulation.

The difference between the REF-B2 and GHG experiments, being the forcing from ODSs, provides an estimate of the effects of ODSs on ozone and temperature in the presence of a changing climate. In rough agreement with previous $2-\mathrm{D}$ modelling and linear regression studies we find ozone depletion and increasing concentrations of $\mathrm{CO}_{2}$ both make approximately equal contributions to cooling near the stratopause over the recent past, though the exact fractional contribution from ozone depletion is sensitive to the period chosen. We find that the decrease in upper stratospheric ozone due to ODSs up to the period 1990-2009, the period of peak ODS concentrations, is between 15 (near $1 \mathrm{hPa}$ ) and $50 \%$ (near $10 \mathrm{hPa}$ ) larger than the actual decrease in ozone in the REF-B2 simulation due to concurrent ozone increases driven by cooling from increasing $\mathrm{CO}_{2}$. The effects of ODSs on the integrated ozone column above $20 \mathrm{hPa}$ are approximately $30 \%$ larger than the REF-B2 change over the same time period. Over the 21 st century, as ODSs slowly decrease, the evolution of upper stratospheric temperature is dominated by GHG-related changes, in particular the increase in cooling from $\mathrm{CO}_{2}$, with only a small warming from ozone increases arising from decreasing ODSs. The upper stratospheric cooling from $\mathrm{CO}_{2}$ also makes a significant contribution to the projected increases in ozone, with decreases in ODSs accounting for approximately $40 \%$ of the increase in ozone above $20 \mathrm{hPa}$ between 1990-2009 and 2080-2099.

Similar to the findings of Waugh et al. (2009), we find that the temporal evolution of the differences between the REF-B2 and GHG runs over the entire simulation closely follows the modelled concentration of halogens over most of the stratosphere. We do find, however, that at high latitudes of the Southern Hemisphere ozone in the lower stratosphere recovers more slowly than would be indicated by the decrease in halogens. The lag in recovery is small, amounting to 2 to $3 \%$ of the annual average ozone concentration in this region, and appears to result from changes in the Antarctic polar vortex from GHGs, either due to temperature effects on PSCs or due to changes in the dynamical isolation of the vortex.

The final simulation of the set, the CHM experiment, included evolving $\mathrm{N}_{2} \mathrm{O}, \mathrm{CH}_{4}$ and ODSs in the chemistry with constant radiative forcing from the long-lived GHGs. As has been previously explored in two-dimensional modelling studies, we find a significant interaction between the GHG forcing and reactive nitrogen chemistry. The increase in the residual circulation of the stratosphere resulting from climate change decreases the transport time of $\mathrm{N}_{2} \mathrm{O}$ from the troposphere to the mid-stratosphere, leaving less time for the photochemical breakdown of $\mathrm{N}_{2} \mathrm{O}$ to produce reactive nitrogen compounds. The increased upwelling results in a decrease in $\mathrm{NO}_{\mathrm{y}}$ through much of the lower stratosphere, despite 
increased tropospheric $\mathrm{N}_{2} \mathrm{O}$. In the mid to upper stratosphere, where reactive nitrogen chemistry is more important, cooling from $\mathrm{CO}_{2}$ alters temperature-sensitive gas-phase chemical rates and results in more rapid loss of $\mathrm{NO}_{\mathrm{y}}$. Countering these influences, we find evidence that the stratospheric lifetime of $\mathrm{N}_{2} \mathrm{O}$ has decreased. The gradient between the tropospheric and mid-stratospheric $\mathrm{N}_{2} \mathrm{O}$ concentration decreases over the course of the experiment more than would be indicated by changes in average transport times, derived from the age of air, alone. The decrease in the stratospheric lifetime of $\mathrm{N}_{2} \mathrm{O}$ results from a more rapid photochemical decay, on average, as more of the $\mathrm{N}_{2} \mathrm{O}$ entering the stratosphere is transported to higher altitudes where photochemical destruction is more rapid. The net effect of these changes on $\mathrm{NO}_{\mathrm{y}}$, as evidenced by the differences between the REF-B2 and CHM simulations, is to moderate the increase in $\mathrm{NO}_{\mathrm{y}}$ resulting from the specified increases in $\mathrm{N}_{2} \mathrm{O}$. Both the REF-B2 and CHM experiments use the same specified increase in $\mathrm{N}_{2} \mathrm{O}$, though the additional effects from the GHGs in REF-B2 simulation result in an increase in $\mathrm{NO}_{\mathrm{y}}$ that is less than $50 \%$ of the increase in $\mathrm{NO}_{\mathrm{y}}$ that occurs in the CHM experiment.

A recent paper by Ravishankara et al. (2009) has put forth the view that with the almost complete cessation of emissions of traditional ODSs covered under the Montreal Protocol, the anthropogenic contribution to emissions of $\mathrm{N}_{2} \mathrm{O}$ has become the dominant ozone depleting substance put into the atmosphere. Our results for $\mathrm{N}_{2} \mathrm{O}$ and $\mathrm{NO}_{\mathrm{y}}$ suggest that projected effects of $\mathrm{N}_{2} \mathrm{O}$ on stratospheric ozone must take into account the significant diminution of the effectiveness of $\mathrm{N}_{2} \mathrm{O}$ as an ozone depleting substance due to climate change.

Acknowledgements. The authors wish to thank Chris McLinden and Nathan Gillett for helpful comments that improved the manuscript and the Canadian Foundation for Climate and Atmospheric Sciences (CFCAS) for the long-running financial support of the C-SPARC network that has allowed for development of the Canadian Middle Atmosphere Model.

Edited by: A. Baumgaertner

\section{References}

Arora, V. K., Boer, G. J., Christian, J. R., Curry, C. L., Denman, K. L., Zahariev, K., Flato, G. M., Scinocca, J. F., Merryfield, W. J., and Lee, W. G.: The effect of terrestrial photosynthesis down regulation on the twentieth-century carbon budget simulated with the CCCma earth system model, J. Climate, 22, 60666088, 2009.

Austin, J. and Wilson, R. J.: Ensemble simulations of the decline and recovery of stratospheric ozone, J. Geophys. Res., 111, D16314, doi:10.1029/2005JD006907, 2006.

Austin, J., Wilson, J., Li, F., and Vömel, H.: Evolution of water vapor concentrations and stratospheric age of air in coupled chemistry-climate model simulations, J. Atmos. Sci., 64, 905921, 2007.
Brasseur, G. and Hitchman, M. H.: Stratospheric response to trace gas perturbations: Changes in ozone and temperature distributions, Science, 240, 634-637, 1988.

Butchart, N., Scaife, A. A., Bourqui, M., de Grandpré, J., Hare, S. H. E., Kettleborough, J., Langematz, U., Manzini, E., Sassi, F., Shibata, K., Shindell, D., and Sigmond, M.: Simulations of anthropogenic change in the strength of the Brewer-Dobson circulation, Clim. Dynam., 27, 727-741, doi:10.1007s00382-0060162-4, 2006.

Butchart, N., Cionni, I., Eyring, V., Shepherd, T. G., Waugh, D. W., Akiyoshi, H., Austin, J., Brühl, C., Chipperfield, M. P., Cordero, E., Dameris, M., Deckert, R., Dhomse, S., Frith, S. M., Garcia, R. R., Gettelman, A., Giorgetta, M. A., Kinnison, D. E., Li, F., Mancini, E., McLandress, C., Pawson, S., Pitari, G., Plummer, D. A., Rozonov, E., Sassi, F., Scinocca, J. F., Shibata, K., Steil, B., and Tian, W.: Chemistry-climate model simulations of 21st century stratospheric climate and circulation changes, J. Climate, doi:10.1175/2010JCLI3404.1, in press, 2010.

Chipperfield, M. P. and Feng, W.: Comment on: Stratospheric Ozone Depletion at northern mid-latitudes in the 21st century: The importance of future concentrations of greenhouse gases nitrous oxide and methane, Geophys. Res. Lett., 30, 1389, doi:10.1029/2002GL016353, 2003.

de Grandpré, J., Sandilands, J. W., McConnell, J. C., Beagley, S. R., Croteau, P. C., and Danilin, M. Y.: Canadian Middle Atmosphere Model: Preliminary results from the chemical transport module, Atmos.-Ocean, 35, 385-431, 1997.

Drdla, K., Gandrud, B. W., Baumgardner, D., Wilson, J. C., Bui, T. P., Hurst, D., Schauffler, S. M., Jost, H., Greenblatt, J. B., and Webster, C. R.: Evidence for the widespread presence of liquidphase particles during the 1999-2000 Arctic winter, J. Geophys. Res., 107, 8318, doi:10.1029/2001JD001127, 2002.

IPCC - Intergovernmental Panel on Climate Change: Special report on emissions scenarios: a special report of Working Group III of the Intergovernmental Panel on Climate Change, Cambridge University Press, Cambridge, UK, 599 pp., 2000.

Engel, A., Möbius, T., Bönisch, H., Schmidt, U., Heinz, R., Levin, I., Atlas, E., Aoki, S., Nakazawa, T., Sugawara, S., Moore, F., Hurst, D., Elkins, J., Schauffler, S., Andrews, A., and Boering, K.: Age of stratospheric air unchanged within uncertainties over the past 30 years, Nature Geosci., 2, 28-31, 2009.

Eyring, V., Butchart, N., Waugh, D. W., et al.: Assessment of temperature, trace species, and ozone in chemistry-climate model simulations of the recent past, J. Geophys. Res., 111, D22308, doi:10.1029/2006JD007327, 2006.

Eyring, V., Waugh, D. W., Bodeker, G. E., Cordero, E., et al.: Multimodel projections of stratospheric ozone in the 21 st century, J. Geophys. Res., 112, D16303, doi:10.1029/2006JD008332, 2007.

Eyring, V., Chipperfield, M. P., Giorgetta, M. A., Kinnison, D. E., Manzini, E., Matthes, K., Newman, P. A., Pawson, S., Shepherd, T. G., and Waugh, D. W.: Overview of the new CCMVal reference and sensitivity simulations in support of upcoming ozone and climate assessments and the planned SPARC CCMVal report, SPARC (Stratospheric processes and their role in climate) Newsletter, 30, 20-26, 2008.

Eyring, V., Cionni, I., Bodeker, G. E., Charlton-Perez, A. J., Kinnison, D. E., Scinocca, J. F., Waugh D. W., et al.: Multi-model assessment of stratospheric ozone return dates and ozone recovery in CCMVal-2 models, Atmos. Chem. Phys. Discuss., 10, 11659- 
11710, doi:10.5194/acpd-10-11659-2010, 2010.

Fomichev, V. I., Jonsson, A. I., de Grandpré, J., Beagley, S. R., McLandress, C., Semeniuk, K., and Shepherd, T. G.: Response of the middle atmosphere to $\mathrm{CO}_{2}$ doubling: Results from the Canadian Middle Atmosphere Model, J. Climate, 20, 11211144, 2007.

Gent, P. R., Bryan, F. O., Danabasoglu, G., Doney, S. C., Holland, W. R., Large, W. G., and McWilliams, J. C.: The NCAR Climate System Model global ocean component, J. Climate, 11, 12871306, 1998.

Haigh, J. D. and Pyle, J. A.: Ozone perturbation in a twodimensional circulation model, Q. J. Roy. Meteorol. Soc., 108, 551-574, 1982

Hegglin, M. I. and Shepherd, T. G.: $\mathrm{O}_{3}-\mathrm{N}_{2} \mathrm{O}$ correlations from the Atmospheric Chemistry Experiment: Revisiting a diagnostic of transport and chemistry in the stratosphere, J. Geophys. Res., 112, D19301, doi:10.1029/2006JD008281, 2007.

Hegglin, M. I. and Shepherd, T. G.: Large climate-induced changes in ultraviolet index and stratosphere-to-troposphere ozone flux, Nat. Geosci., 2, 687-691, 2009.

Holton, J. R., Haynes, P. H., McIntyre, M. E., Douglass, A. R., Rood, R. B., and Pfister, L.: Stratosphere-troposphere exchange, Rev. Geophys., 33, 403-439, 1995.

Jonsson, A. I., de Grandpré, J., Fomichev, V. I., McConnell, J. C., and Beagley, S. R.: Doubled $\mathrm{CO}_{2}$-induced cooling in the middle atmosphere: Photochemical analysis of the ozone radiative feedback, J. Geophys. Res., 109, D24103, doi:10.1029/2004JD005093, 2004.

Jonsson, A. I., Fomichev, V. I., and Shepherd, T. G.: The effect of nonlinearity in $\mathrm{CO}_{2}$ heating rates on the attribution of stratospheric ozone and temperature changes, Atmos. Chem. Phys., 9, 8447-8452, doi:10.5194/acp-9-8447-2009, 2009.

Li, F., Austin, J., and Wilson, J.: The strength of the BrewerDobson circulation in a changing climate: coupled chemistryclimate model simulations, J. Climate, 21, 40-57, 2008.

McLandress, C. and Shepherd, T. G.: Simulated anthropogenic changes in the Brewer-Dobson circulation, including its extension to high latitudes, J. Climate, 22, 1516-1540, 2009.

McLandress, C., Jonsson, A. I., Plummer, D. A., Reader, M. C., Scinocca, J. F., and Shepherd, T. G.: Separating the dynamical effects of climate change and ozone depletion: Part 1, Southern Hemisphere stratosphere, under revision, J. Climate, 2010.

Montzka, S. A., Butler, J. H., Elkins, J. W., Thompson, T. M., Clarke, A. D., and Lock, L. T.: Present and future trends in the atmospheric burden of ozone-depleting halogens, Nature, 398, 690-694, 1999

Oman, L., Waugh, D. W., Pawson, S., Stolarski, R. S., and Nielsen, J. E.: Understanding the changes in stratospheric water vapor in coupled chemistry-climate model simulations, J. Atmos. Sci., 65, 3278-3291, 2008.

Oman, L. D., Waugh, D. W., Kawa, S. R., Stolarski, R. S., Douglass, A. R., and Newman, P. A.: Mechanisms and feedback causing changes in upper stratospheric ozone in the 21st century, J. Geophys. Res., 115, D05303, doi:10.1029/2009JD012397, 2010.

Portmann, R. W. and Solomon, S.: Indirect radiative forcing of the ozone layer during the 21st century, Geophys. Res. Lett., 34, L02813, doi:10.1029/2006GL028252, 2007.

Randel, W. J. and Wu, F.: A stratospheric ozone profile data set for 1979-2005: Variability, trends, and comparisons with column ozone data, J. Geophys. Res., 112, D06313, doi:10.1029/2006JD007339, 2007.

Randel, W. J., Shine, K. P., Austin, J., Barnett, J., Claud, C., Gillett, N. P., Keckhut, P., Langematz, U., Lin, R., Long, C., Mears, C., Miller, C., Nash, J., Seidel, D. J., Thompson, D. W. J., Wu, F., and Yoden, S.: An update of observed stratospheric temperature trends, J. Geophys. Res., 114, D02107, doi:10.1029/2008JD010421, 2009.

Randeniya, L. K., Vohralik, P. F., and Plumb, I. C.: Stratospheric ozone depletion at northern mid-latitudes in the 21 st century: The importance of future concentrations of greenhouse gases nitrous oxide and methane, Geophys. Res. Lett., 29, 1051, doi:10.1029/2001GL014295, 2002.

Ravishankara, A. R., Daniel, J. S., and Portmann, R. W.: Nitrous oxide $\left(\mathrm{N}_{2} \mathrm{O}\right)$ : The dominant ozone-depleting substance emitted in the 21st century, Science, 326, 123-125, 2009.

Rosenfield, J. E. and Douglass, A. R.: Doubled $\mathrm{CO}_{2}$ effects on $\mathrm{NO}_{\mathrm{y}}$ in a coupled 2D model, Geophys. Res. Lett., 25, 4381-4384, 1998.

Rosenfield, J. E., Douglass, A. R., and Considine, D. B.: The impact of increasing carbon dioxide on ozone recovery, J. Geophys. Res., 107, 4049, doi:10.1029/2001JD000824, 2002.

Rosenfield, J. E., Frith, S. M., and Stolarski, R. S.: Version 8 SBUV ozone profile trends compared with trends from a zonally averaged chemical model, J. Geophys. Res., 110, D12302, doi:10.1029/2004JD005466, 2005.

Santer, B. D., Wigley, T. M. L., Boyle, J. S., Gaffen, D. J., Hnilo, J. J., Nychka, D., Parker, D. E., and Taylor, K. E.: Statistical significance of trends and trend differences in layer-average atmospheric temperature time series, J. Geophys. Res., 105, 7337 7356, 2000.

Scinocca, J. F., McFarlane, N. A., Lazare, M., Li, J., and Plummer, D.: Technical Note: The CCCma third generation AGCM and its extension into the middle atmosphere, Atmos. Chem. Phys., 8, 7055-7074, doi:10.5194/acp-8-7055-2008, 2008.

Shepherd, T. G.: Dynamics, stratospheric ozone and climate change, Atmos.-Ocean., 46, 117-138, 2008.

Shepherd, T. G. and Jonsson, A. I.: On the attribution of stratospheric ozone and temperature changes to changes in ozonedepleting substances and well-mixed greenhouse gases, Atmos. Chem. Phys., 8, 1435-1444, doi:10.5194/acp-8-1435-2008, 2008.

Shine, K. P., Bourqui, M. S., Forster, P. M. F., Hare, S. H. E., Langematz, U., Braesicke, P., Grewe, V., Ponater, M., Schnadt, C., Smith, C. A., Haigh, J. D., Austin, J., Butchart, N., Shindell, D. T., Randel, W. J., Nagashima, T., Portmann, R. W., Solomon, S., Seidel, D. J., Lanzante, J., Klein, S., Ramaswamy, V., and Schwarzkopf, M. D.: A comparison of model-simulated trends in stratospheric temperatures, Q. J. Roy. Meteorol. Soc., 129(590), 1565-1588, 2003.

Son, S.-W., Polvani, L. M., Waugh, D. W., Birner, T., Akiyoshi, H., Garcia, R. R., Gettelman, A., Plummer, D. A., and Rozanov, E.: The impact of stratospheric ozone recovery on tropopause height trends, J. Climate, 22, 429-445, 2009.

SPARC CCMVal: SPARC CCMVal Report on the Evaluation of Chemistry-Climate Models, edited by: Eyring, V., Shepherd, T. G., and Waugh, D. W., SPARC Report No. 5, WCRP-132, WMO/TD-NO. 1526., http://www.atmosp.physics.utoronto.ca/ SPARC, 2010 
Waugh, D. W. and Eyring, V.: Quantitative performance metrics for stratospheric-resolving chemistry-climate models, Atmos. Chem. Phys., 8, 5699-5713, doi:10.5194/acp-8-5699-2008, 2008.

Waugh, D. W., Oman, L., Kawa, S. R., Stolarski, R. S., Pawson, S., Douglass, A. R., Newman, P. A., and Nielsen, J. E.: Impacts of climate change on stratospheric ozone recovery, Geophys. Res. Lett., 36, L03805, doi:10.1029/2008GL036223, 2009.

World Meteorological Organization (WMO)/United Nations Environment Programme (UNEP): Scientific Assessment of Ozone Depletion: 2006, World Meteorological Organization, Global Ozone Research and Monitoring Project, Report No. 50, Geneva, Switzerland, 2007.
Yang, E.-S., Cunnold, D. M., Salawitch, R. J., McCormick, M. P., Russell III, J., Zawodny, J. M., Oltmans, S., and Newchurch, M. J.: Attribution of recovery in lower-stratospheric ozone, J. Geophys. Res., 111, D17309, doi:10.1029/2005JD006371, 2006. 